\title{
ЧУЖІ СВОЇ? АСПІРАНТИ ІВАНА КРИП' ЯКЕВИЧА У ЛЬВІВСЬКОМУ УНІВЕРСИТЕТІ: СПРОБА ПРОСОПОГРАФІЧНОГО ПОРТРЕТУ
}

\author{
Олександр ЦЕЛУЙКО \\ Львівський національний університет імені Івана Франка, \\ кафедра давньої історії України та архівознавства \\ вул. Університетська 1 , Львів 79000, Україна \\ e-mail: o_celujko@meta.ua
}

У Львівському університеті підготова наукових та науково-педагогічних працівників через аспірантуру була запроваджена у рамках його радянізації. Перший набір до аспірантури провели восени-взимку 1940-1941 pp. Тоді до складу аспірантів історичного факультету першого року навчання було зараховано четверо осіб, двоє з яких (Валентина Лелюх та Олександр Куліков) по кафедрі історії України. Їх офіційне перебування в аспірантурі почалося 1 лютого 1941 р. і мало б завершитися 31 січня 1944 р. У середині лютого 1941 р. до їх числа приєднався Антон Криленко, котрий у Львівському університеті був зарахований аспірантом другого року навчання - він уже перебував свого часу в аспірантурі у Києві. Офіційним керівником аспірантів по кафедрі історії України було призначено відомого українського вченого професора Івана Крип'якевича.

У результаті детального вивчення біографій аспірантів Львівського університету, котрі навчалися по цій кафедрі, з'ясувалось, що всі вони були вихідцями із східних областей України, лише нещодавно приїхали до Львова, були членами ВКП(б), працювали викладачами університетської кафедри марксизму-ленінізму. Вони не мали за собою ні більшого наукового досвіду, ні жодних публікацій, не знали чужоземних мов, однак, що важило для радянського керівництва, були цілком благонадійні. Усе це дозволяє стверджувати про особливий підбір аспірантів по кафедрі історії України порівняно із іншими кафедрами Університету.

Роботу зі своїми аспірантами I. Крип'якевич розпочав наприкінці січня 1941 р. Саме тоді було накреслено план їх подальшої праці, розпочато лекційні виклади, попередньо намічено тематику їх наукових студій. У роботі з аспірантами I. Крип'якевич намагався використати той досвід, котрий він свого часу отримав під час навчання в Університеті та свого формування як дослідника. Він провадив індивідуальні консультації, укладав списки необхідної для аспірантів літератури, прочитав для них спеціяльний курс “Методології історії”. У той же час I. Крип’якевич був змушений прилаштуватися до офіційних радянських вимог. Початок радянсько-німецької війни завадив згаданим аспірантам продовжити їх наукові студії. Двоє із них (А. Криленко та О. Куліков) загинули у роки війни; не повернулася до навчання і В. Лелюх.

Свою роботу у Львівському університету аспірантура відновила у повоєнний час. У грудні 1945 р. до зарахування в аспірантуру по кафедрі історії України рекомендували Ніну Цимбал та Володимира Бориса, а їхнім науковим наставником знову призначили професора I. Крип'якевича. Через деякий час В. Бориса перевели в аспірантуру по іншій кафедрі, і під керівництвом I. Крип'якевича залишилася працювати лише Н. Цимбал. Наступного навчального року до аспірантури по кафедрі історії України поступив ще один випускник історичного факультету Василь Інкін, а у жовтні 1947 р. аспіранткою стала випускниця Львівського державного педагогічного інституту Ольга Омельчук. Попрацювати з ними професорові І. Крип'якевичу довший час не довелося, оскільки восени 1946 р., $з$ початком ідеологічної кампанії боротьби зі школою М. Грушевського, він був змушений переїхати до Києва. Це значно утруднило контакти між ним та його аспірантами. Ситуація погіршилася, коли в листопаді 1947 р. І. Крип’якевич був 
ISSN 2078-6077. Наукові зошити історичного факультету Львівського університету. 2020. Випуск 21. Proceedings of History Faculty of Lviv University. 2020. Issue 21.

офіційно звільнений з роботи в університеті. У подальшому згаданим аспірантам призначили нового наукового керівника. Зреалізувати себе як наставника наукової молоді, сформувати навколо себе групу осіб, котрі б продовжили його працю, І. Крип'якевичу вдалося лише у наступні роки.

Ключові слова: Львівський університет, Іван Крип’якевич, аспірантура, кафедра історії України.

Теза про те, що Іван Петрович Крип’якевич був чи не найвидатнішим в Україні істориком повоєнної доби (чи, фактично, усієї другої половини 1940-1960-х рр.), видатним організатором історичної науки того часу настільки міцно вкорінена в сучасній вітчизняній історіографії, що стала своєрідною аксіомою. Дійсно, вихід монументальної монографії “Богдан Хмельницький” (1954) та низки надзвичайно важливих і цікавих статтей, праця вченого у Львівському університеті (19391941, 1944-1947) та у місцевому філіялі Інституту історії України (1940-1941, 1944-1946), його діяльність з інституалізації української науки у створеному в 1951 р. Інституті суспільних наук АН УРСР перетворювали Івана Петровича на величину першого порядку у тогочасному українському науковому світі, при чому величину, яка здобула визнання як у середовищі радянських вчених та партійних функціонерів - ознакою чого було присвоєння йому у 1958 р. звання академіка ${ }^{1}$, так і поміж української діяспори. Наголосимо на ще одній обставині. Якщо дивитися на галицьке українське історіописання як безперервний процес, то як для того часу, так і для нас I. Крип'якевич був і зостається певним символом, тією сполучною ланкою, котра поєднує між собою дві епохи: епоху класичної, старої, т. зв. “дорадянської” історичної науки, яку ми пов'язуємо 3 іменем М. Грушевського, та епоху середини і другої половини ХХ ст. Ба, більше! Через своїх учнів і послідовників, через те гроно молодих дослідників 19501960-их рр., котрі вважали і вважають І. Крип'якевича своїм наставником, тяглість продовжено до наших днів. Не дивно, що постать цього видатного історика вже давно є об'єктом прискіпливих студій українських вітчизняних і закордонних вчених, що засвідчує низка дисертаційних робіт (I. Мороз (Заболотна), Я. Кондрач, Ю. Лєбєдєва, Т. Литвин, Н. Клименко), наукових збірників ${ }^{2}$, окремих публікацій та статтей, число яких постійно зростає $\epsilon^{3}$. У той

\footnotetext{
${ }^{1}$ Додамо, що ще раніше, наприкінці 1953 р., Вчена Рада Львівського університету підтримала висунення І. Крип“якевича у члени-кореспонденти АН УРСР по відділу історії, однак тоді його обрання на це місце не відбулося. Див.: Протоколи і стенограми засідань Вченої Ради університету та матеріали до них, т. 2 і останній, 30 червня 1953 р. - 7 грудня 1953 р., Державний архів Львівської області (далі - ДАЛО), ф. Р-119, оп. 8, спр. 22, арк. 68, 73-74.

${ }^{2}$ Тут особливо необхідно відзначити підготовані працівниками Інституту українознавства ім. I. Крип'якевича НАН України збірники Іван Крип 'якевич у родинній традичіï, науці, суспільстві. (Украӥна: культурна спадщина, начіональна свідомість, державність. Зб. наук. пращь), по. 8, (2001); no. 28, (2016).

3 Докладний перелік публікацій про І. Крип'якевича див. у: Іван Крип'якевич у родинній традиціï, науці, суспільстві, по. 28: 697-711. Див. також: Інна Заболотна, “Історіографія життя та наукової спадщини I. П. Крип'якевича,” Історіографічні дослідження в Україні, no. 17, (2017): 210-217.
} 
же час помітними стають і ті лакуни, які, з тих чи інших причин, залишилися поза увагою авторів дотеперішніх студій, або ж питання, які слід вивчати ретельніше. До них, зокрема, зараховуємо навчальну та організаційну діяльність I. Крип'якевича на посаді завідувача кафедри історії України Львівського університету ${ }^{4}$ та такий практично недосліджений до наших днів їі аспект, як робота з аспірантами цієї кафедри. Додаткове сум`яття вносить і та обставина, що наша спроба віднайти якийсь усталений в українській історіографії список учнів І. Крип'якевича хоча і виявила істотні розбіжності в їх персональному складі ${ }^{5}$, що, зрештою, можна пояснити відмінними індивідуальними практиками укладачів цих списків, однак, у той же час, чітко окреслила хронологічні рамки, в яких потрібно провадити такі пошуки - 1950-1960-ті рр., тобто час, коли I. Крип'якевич до Львівського університету мав лише дотичний i, як правило, спорадичний стосунок (наприклад, головував у Державній екзаменаційній комісії на історичному факультеті, опонував дисертаційні роботи тощо), зосередившись на роботі в Інституті суспільних наук та, у подальшому, керівництві Теоретичним семінаром з джерелознавства та спеціяльних (допоміжних) історичних дисциплін, що запрацював при Центральному державному історичному архіві УРСР у м. Львові у 1961 р. ${ }^{6}$. Однак відомо, що підготовою аспірантів професор керував не лише у згаданому вище Інституті, але й в Університеті. Імена довоєнних

\footnotetext{
${ }^{4}$ Частково див. про це: Олександр Целуйко, “Кафедра історії України у 1944-1949 рр.: від учнів Михайла Грушевського до апологетів радянського світу,” Вісник Львівського університету. Серія історична, по. 54, (2018) [в друці].

5 Для прикладу, івано-франківський історик Володимир Грабовецький (1928-2015) стверджуючи існування “Львівської історичної школи академіка Івана Крип'якевича”, зараховував до неї, окрім себе, Володимира Барана, Ярослава Дашкевича, Ярослава Ісаєвича, Миколу Кравця, Феодосія Стеблія, Юрія Сливку та Степана Білецького. Див.: Володимир Грабовецький, “Львівська історична школа академіка Івана Крип'якевича. Учні Львівської історичної школи Івана Крип'якевича 50-70-х років XX ст. та їх наукові здобутки,” в Академік Іван Крип'якевич, (Іван-Франківськ, 2005): 54. Ці ж прізвища учнів І. Крип’якевича перелічено у М. Кучернюка та І. Іванцева. Див.: Микола Кучернюк і Ігор Іванцев, “Іван Крип'якевич та його львівська школа істориків,” в Тези доповідей та повідомлень регіональної науково-теоретичної конферениії, присвяченої 105-річчю з дня народження визначного історика Украӥни, академіка Івана Крип'якевича, (Івано-Франківськ, 1991): 16-17. Натомість львівський історик Іван Сварник у статті до біо- бібліографічного довідника "Українські архівісти” зараховує до числа учнів I. Крип'якевича Олега Купчинського, Едуарда Ружицького, Ореста Мацюка, Олексія Маркевича, Віталія Гавриленка, Пелагею Захарчишин, Марію Вавричин та Ярослава Ісаєвича. Див.: Іван Сварник, “Крип' якевич Іван Петрович,” в Украӥнські архівісти (XIX-XX cm.). Біо-бібліографічний довідник, (Київ, 2007): 325.

${ }^{6}$ Дивись про нього: Валентина Бездрабко, “Семінар з архівознавства та допоміжних історичних дисциплін ЦДІА України у Львові: науковий феномен,” Записки Львівської наукової бібліотеки ім. В. Стефаника: Збірник наукових праць, по. 1 (16), (2008): 546-579; Валентина Бездрабко, Документознавство в Україні: інституиіоналізація та сучасний розвиток. (Київ: "Четверта хвиля”, 2009), 139-170; Олександр Целуйко, “В. В. Зварич та питання нумізматики в роботі теоретичного семінару з джерелознавства та спеціальних (допоміжних) історичних дисциплін при Центральному державному історичному архіві УРСР у Львові," Наукові зошити історичного факультету Львівського університету, по. 16, (2015): С. 24-39.
} 
ISSN 2078-6077. Наукові зошити історичного факультету Львівського університету. 2020. Випуск 21. Proceedings of History Faculty of Lviv University. 2020. Issue 21.

аспірантів I. Крип'якевича перерахував у одній зі своїх публікацій Олександр Луцький ${ }^{7}$, повоєнних (1946-1947рр.) названо у підготованій за нашої участи в 2000 р. "Ювілейній книзі історичного факультету [Львівського університету]". Однак це були лише імена. Ким були ці люди, як вони опинилися на кафедрі історії України Львівського університету, якою була тематика їх дисертаційних робіт - питання, яке варто було б розв'язати сучасній історіографії. Перший крок у цьому керунку зроблено в одній із наших публікацій ${ }^{9}$ Однак у ній, переважно, йшлося про одного із аспірантів проф. І. Крип'якевича - Василя Фадейовича Інкіна. Прийшов час розповісти й про інших осіб, котрим пощастилодовше чи менше - попрацювати під орудою Івана Петровича. Виконати це завдання і покликана наша публікація. Крізь призму оприлюднених біографічних фактів, навчальних та методичних матеріялів, що відклалися в Архіві Львівського університету, Державному архіві Львівської області, в особовому фонді Івана Крип'якевича у Львівській національній науковій бібліотеці імені Василя Стефаника НАН України, спробуємо дати відповідь на ще одне важливе питання: наскільки успішною була робота I. Крип'якевича з аспірантами у Львівському університеті, та які результати вона принесла.

“Радянізація" Львівського університету розпочалася після приходу Червоної Армії на західноукраїнські землі восени 1939 p. ${ }^{10}$ Уже в жовтні ректором призначили історика Михайла Марченка, якому доручили перебудувати роботу університету за новим взірцем. Це неминуче мало б привести і до істотної структурної реорганізації цієї інституції, і до поступового реформування всього навчального процесу. Наказом Всесоюзного комітету у справах вищої школи при РНК СРСР (далі - ВКВШ СРСР) від 1 грудня 1939 р. Університет Яна Казимира перейменовано у Львівський державний університет ${ }^{11}$; наприкінці

\footnotetext{
${ }^{7}$ Олександр Луцький, “Науково-організаційна і педагогічна діяльність І. П. Крип’якевича у вересні 1939 - червні 1941 рр.,” Іван Крип 'якевич у родинній традиції, науці, суспільстві (Украӥна: культурна спадщина, національна свідомість, державність. Зб. наук. праць), по. 8: 798.

${ }^{8}$ Історичний факультет Львівського національного університету імені Івана Франка (19402000). Ювілейна книга, упоряд. Олексій Вінниченко та Олександр Целуйко. (Львів, 2000), 183.

${ }^{9}$ Олександр Целуйко, “Про одну ненаписану дисертацію. Причинок до вивчення історії галицько-волинської держави у повоєнну добу,” Вісник Львівського університету. Серія історична, по. 52, (2016): 176-199.

${ }^{10}$ Про перебудову роботи Львівського університету у 1939-1940 pр. та його структуру в цей час див.: Володимир Качмар, “Реорганізація Львівського університету (1939-1940),” Наукові зошити історичного факультету. Львівський національний університет імені Івана Франка, no. 7, (2005): 328-338; Adam Redzik, "Uniwersytet Lwowski w latach 1939-1946," w Academia militans. Uniwersytet Jana Kazimierza we Lwowie, red. Adam Redzik. (Kraków: Wysoki Zamek, 2015): 915-988.

${ }^{11}$ Указ Президиума Верховного Совета УССР о присвоении университету им.[ени] Ивана Франко, приказы ВШВК при СНК СССР о проведении экзаменационной сессии и утверждении персонального состава государственных экзаменационных комиссий, 1 грудня 1940 р. - 7 квітня 1941 р., ДАЛО. ф. Р-119, оп. 3, спр. 29, арк. 1. Порівняй: Володимир Качмар, “Між “радянізацією” та “українізацією”: діяльність Михайла Марченка на посаді ректора Львівського університету в 1939-1940 роках," в Львів: місто - суспільство - культура, (Краків: Наукове
} 
1939 - на початку 1940 р. у його складі було виокремелено історичний факультет. Дещо раніше, у жовтні того ж року, створено кафедру історії України, виконувачем обов'язків завідувача якої призначили І. Крип'якевича ${ }^{12}$. Він, фактично, i був ії єдиним штатним викладачем. Попри це кафедра історії України була однією 3 двох факультетських кафедр, яка могла похвалитися значним числом аспірантів. У Львівському університеті цю радянську систему підготови наукових та науково-педагогічних працівників через аспірантуру було запроваджено у рамках його радянізації. Документи для ії відкриття готувалися ще за часів ректорства М. Марченка (клопотання про це Рада університету ухвалила на своєму засіданні 4 липня $1940 \mathrm{p} \cdot{ }^{13}$ ), а за його наступника - Г. Биченка (той змінив М. Марченка на цій посаді у вересні того ж року) восени-взимку 1940 p. ${ }^{14}$ провели перший набір за певними напрямками підготови, у тому числі історії України та археології.

Для цього наказом ректора від 21 жовтня 1940 р. в університеті створили спеціяльну конкурсну комісію на чолі із проректором 3 наукової частини академіком Кирилом Студинським. До ії складу увійшли декани факультетів В. Сімович (філологічного), А. Брагінець (історичного), П. Недбайло (юридичного), С. Банах (фізико-математичного), С. Біскупський (природничого) та професори Ю. Полянський і С. Рєзніков. Ця комісія на своєму засіданні 23 жовтня 1940 р. повинна була провести попередній відбір серед вступників, розглянувши та схваливши заяви від претендентів на місце в аспірантурі, та

видавництво Педагогічної Академії, 2005), t. V. Люди Львова, 146-147 Див. про це також свідчення М. Марченка, які він давав у часі слідства: “Власноручні свідчення в'язня М. І. Марченка про його роботу ректором Львівського державного університету ім. I. Франка у 1939-1940 pp., 30 травня 1943 р.," в Інститут історії Украӥни Національної академії наук України. Документи і матеріали. 1936-1991 (К.: Інститут історії України НАН України, 2011), кн. 1. 1936-1947, 377-399.

${ }^{12}$ Наказ про створення кафедри історії України датовано 18 жовтням 1939 р. Див.: Володимир Качмар, “Реорганізація Львівського університету (1939-1940),”: 329. Професором кафедри історії України І. Крип'якевич був призначений 24 жовтня 1939 р. Богдана Сипко, “Викладацький склад історичного факультету Львівського університету у 1940 р. крізь призму службових характеристик," Вісник Львівського університету. Серія історична, по. 50 (2014):460, 466; Накази ректора за 1939 р., 1939, Архів Львівського національного університету імені Івана Франка (далі - Архів ЛНУ), ф. Р-119, оп. 3, спр. 3, арк. 7. Про діяльність І. Крип’якевича на посаді завідувача кафедри історії України Львівського університету у 1939-1941 рр. див.: Олександр Луцький, "Науково-організаційна і педагогічна діяльність І. П. Крип’якевича у вересні 1939 червні 1941 рр.,”: 783-800. Про кафедру історії України у 1939-1949 рр. див.: Юрій Киричук і Костянтин Кондратюк, “Кафедра новітньої історії України,” в Історичний факультет Львівського національного університету, 7-8 та згадану вище нашу статтю.

${ }^{13}$ Протоколы заседаний Научного Совета и приказ Всесоюзного комитета по делам высшей школы при СНК СССР от 15 апреля 1940 г. об утверждении состава ученого совета, 4 грудня 1939 р. - 15 квітня 1940 р., ДАЛО, ф. Р-119, оп. 3, спр. 64, арк. 46-47.

${ }^{14}$ Історичний факультет Львівського національного університету, 183. Наказ ВКВШ СРСР і НКО про відкриття аспірантури (30 чоловік) у Львівському університеті датовано 2 вереснем 1940 р.: Володимир Качмар і Ярослав Притула, “Історичний факультет у структурі Львівського університету: 1940 рік,” Вісник Львівського університету. Серія історична, по. 50: 439. 
ISSN 2078-6077. Наукові зошити історичного факультету Львівського університету. 2020. Випуск 21. Proceedings of History Faculty of Lviv University. 2020. Issue 21.

подати відповідні рекомендації для керівництва університету ${ }^{15}$. Іншим наказом ректора від 22 жовтня того ж року створили факультетські комісії для прийому впродовж 4-6 листопада іспитів (з основ марксизму-ленінізму, чужоземної мови та за спеціяльностю) у вступників. На історичному факультеті до комісії увійшли декан А. Брагінець (екзаменатор із основ марксизму-ленінізму), професори I. Крип'якевич (екзаменатор з історії України) та Я. Пастернак (екзаменатор 3 археології), старший викладач К. Загаєвський (екзаменатор з німецької мови) і викладачі Е. Дешберг (англійська мова) і Я. Гольдман (французька мова) ${ }^{16}$. Відомо, що університетська конкурсна комісія розглянула заяви і допустила до подальших випробувань 10 осіб (Кобильчака Івана Кириловича, Трояновського Семена С., Вольтер Хану Мордхаївну, Тимофієнка Андрія Івановича, Смолякова Івана Андрійовича, Лелюх Валентину Михайлівну, Мариновича Антона А., Кулікова Олександра Захаровича, Тимчука Романа Івановича, Ріхтер Н. А.), 3 яких трьох (Х. Вольтер, В. Лелюх та А. Мариновича) лише умовно - ті додатково повинні були подати характеристики з місця праці чи інших установ ${ }^{17}$. Зрештою, іспити 3 них здавало четверо (В. Лелюх, Р. Тимчук, О. Куліков та А. Тимофієнко $)^{18}$. Очевидно, подібними були висліди роботи екзаменаційних комісій на інших факультетах. Як наслідок, у зв'язку із недобором з окремих напрямків ${ }^{19}$ (у тому числі й археологіï) у грудні того ж року оголосили додатковий набір до аспірантури Львівського університету ${ }^{20}$. Саме тоді до іспитів допустили ще одного історика - Григорія Самчука ${ }^{21}$. Загалом за результатами цих випробувань у січні 1941 р. до складу аспірантів історичного факультету першого року навчання зараховали четверо осіб, двоє з яких (Р. Тимчук та Г. Самчук) по кафедрі археології, а інші (В. Лелюх та О. Куліков) - історії України ${ }^{22}$. Їх

${ }^{15}$ Накази ректора за 1940 р. (друга половина), 1940, Архів ЛНУ, ф. Р-119, оп. 3, спр. 31, арк. 211. Згадку про цю конкурсну комісію див.: Ольга Гнатюк, Biдвага i cmpax. (Київ.: ДУХ I ЛITЕРА, 2017), 394.

${ }^{16}$ Накази ректора за 1940 р. (друга половина), 212-213.

${ }^{17}$ Накази ректора за 1940 р. (друга половина), 248-249.

${ }_{18}^{18}$ Відділ кадрів. Списки осіб, рекомендованих до аспірантури, [1940], Архів ЛНУ, ф. Р-119, оп. 1, спр. 1458, арк. 1-2.

${ }^{19}$ Рада Львівського університету на своєму засіданні в липні 1940 р. просила ВКВШ СРСР відкрити на історичному факультеті аспірантуру для семи чоловік, на фізико-математичному - для десяти, наприродничому - для 15 , на філологічному-для 18 і на юридичному-для восьми (Протоколы заседаний Научного Совета и приказ Всесоюзного комитета по делам высшей школы при СНК СССР от 15 апреля 1940 г. об утверждении состава ученого совета, арк. 47). Остаточне число місць в аспірантурі, які були затверджені для Львівського університету у Москві, нам не відоме.

${ }^{20}$ Приказы и распоряжения Всесоюзного комитета по делам высшей школы при СНК СССР о приеме в аспирантуру с приложением Положения об аспирантуре, 31 березня 1939 р. 30 жовтня 1940 р., ДАЛО. Ф. Р-119, оп. 3, спр. 150, арк. 20.

${ }^{21}$ Накази ректора за 1940 р. (друга половина), 368.

${ }^{22}$ Відділ кадрів. Списки аспірантів, 20 січня 1941 р. - 8 квітня 1941 р., Архів ЛНУ, ф. Р-119, оп. 1, спр. 1457, арк. 2 (Копія наказу № 132 заступника народного комісара освіти УРСР Філіпова О. М. від 20 січня 1941 р.); Накази ректора [Львівського університету] за 1941 р., 1941 р., Архів Львівського національного університету імені Івана Франка (далі - Архів ЛНУ), ф. Р-119, оп. 3, спр. 52, арк. 35; Історичний факультет Львівського національного університету, 183. 
офіційне перебування в аспірантурі починалося 1 лютого 1941 р. і мало завершитися 31 січня 1944 р. У середині лютого 1941 р. до числа аспірантів по кафедрі історії України приєднався Антон Корнійович Криленко, котрий уже свого часу перебував в аспірантурі у Києві, а тому його у Львівському університеті відразу зарахували аспірантом другого року навчання²3. Офіційними керівниками аспірантів-істориків призначили Ярослава Пастернака та I. Крип’якевича. Чому саме цим галицьким вченим було доручено готувати майбутніх науковців на історичному факультеті? Справа в тому, що згідно з чинним на той час положенням, керівником аспірантів міг бути лише професор чи доктор наук ${ }^{24}$. Якщо відкинути представників старої польської професури (таких як Т. Модельський, В. Подляха, К. Маєвський, Е. Булянда, Ф. Буяк), котрі продовжували працювати на "ідеологічному" історичному факультеті в радянському університеті, але були для нової влади чужими ${ }^{25}$, та новоприбулих радянських вчених, серед яких єдиним “захищеним” кандидатом історичних наук (та й то нещодавно, у лютому 1940 р.) був Свсевій Одрина ${ }^{26}$, на факультеті залишалося лише двоє українських професорів, керівників кафедр, котрі могли би перебрати на себе ці обов'язки - I. Крип'якевич та Я. Пастернак. Щоправда, обидва на той час ще не отримали офіційного підтвердження від радянських органів влади своїх наукових ступенів та вчених звань, однак відповідні документи вже перебували на розгляді в Києві та Москві, і було зрозуміло, що ця справа вирішиться для них позитивно ${ }^{27}$. До того ж обидва, як зазначалося вище, уже були завідувачами кафедр та мали за своїми плечима значний

${ }^{23}$ Накази ректора [Львівського університету] за 1941 р., 96.

${ }^{24}$ Про це йшлося й у положенні про аспірантуру від 1939 р.; на цьому наголошувалося у наказі ВКВШ СРСР від 26 травня1940 р. Втім, як показала повоєнна практика, від суворого дотримання цієї норми довелося відмовитися за браком необхідного числа відповідних наукових кадрів.

${ }^{25}$ Прикметно, що польських професорів допустили до керівництва аспірантами на всіх інших факультетах університету, окрім історичного. Див.: Відділ кадрів. Списки аспірантів, [1941], Архів ЛНУ, ф. Р-119, оп. 1, спр.1456, арк. 1; Відділ кадрів. Списки аспірантів, 20 січня 1941 р. 8 квітня 1941 р., арк. 1. Дивись, для порівняння, про перших аспірантів фізико-математичного факультету Львівського університету в: Ярослав Притула, “Аспірантура на фізикоматематичному факультеті у 1940-1941 роках," Механіко-математичний факультет Львівського національного університету ім. Івана Франка, 23 лютого 2017, доступ отримано 20 жовтня 2017, http://www.mmf.lnu.edu.ua/istoriia/istoriia-fakultetu/1528.

26 У травні 1940 р. захистив кандидатську дисертацію ректор М. Марченко, однак тоді, коли зараховували пошукувачів до аспірантури, він у Львівському університеті вже не працював. Декан історичного факультету А. Брагінець був доцентом, кандидатом філософських наук. Призначений восени 1940 р. ректор Г. Биченко нібито був кандидатом технічних (!) наук. Див.: Інститут історії України Національної академії наук України. Документи і матеріали, 394, 410; Христина Ковтун та Андрій Синиця, “Андрій Брагінець - перший декан історичного факультету Львівського університету,” в Вісник Львівського університету. Серія історична, по. $50: 185$.

${ }^{27}$ Офіщійно І. Крип'якевичу присвоїли ступінь доктора історичних наук і надали вчене звання професора у квітні 1941 р. Див.: Ярослав Ісаєвич, “Крип’якевич Іван Петрович,” в Енциклопедія історії України. (Київ, 2008), т. 5, 392; Списки преподавателей, имеющих ученое звание профессора, и выписки из протоколов заседаний высшей аттестационной комиссии об утверждении преподавателей в ученом звании и ученой степени, 12 березня 1941 р. - 7 червня 1941 р., Архів ЛНУ, ф. Р-119, оп. 1, спр. 413, арк. 15 (Витяг з протоколу засідання ВАК СРСР від 5 квітня 1941 р., № 13). 
ISSN 2078-6077. Наукові зошити історичного факультету Львівського університету. 2020. Випуск 21. Proceedings of History Faculty of Lviv University. 2020. Issue 21.

науковий багаж, a I. Крип'якевич був ще й призначений керівником новоствореного Львівського відділення Інституту історії АН УРСР.

Отже, по кафедрі історії України у лютому 1941 р. аспірантами було зараховано (чи, як справедливо зауважив О. Луцький, “призначено” ${ }^{28}$ ) трьох осіб - Антона Корнійовича Криленка, Валентину Михайлівну Лелюх та Олександра Захаровича Кулікова. 3' ясуймо, ким були ці аспіранти кафедри історії України. Один з них - Антон Корнійович Криленко - народився 10 липня 1912 p. у с. Васьківці Заславського повіту Подільської губернії (тепер - Ізяславський район Хмельницької обл.) в селянській сім'ї, українець. Після закінчення семирічної школи у м. Заславлі навчався на Київському робфаці, а у подальшому закінчив історичний факультет Київського педагогічного інституту імені М. Горького (1934-1937). Був членом ВЛКСМ (1927) та ВКП(б) (1939). У вересні 1938 р. його зарахували до аспірантури київського Українського науководослідного інституту педагогіки, однак навчання в ній А. Криленко не завершив у грудні 1939 р. його, як молодого партфункціонера, скеровують на західноукраїнські землі для допомоги в їх радянізації. Деякий час він працював секретарем з пропаганди Львівського обласного комітету ЛКСМУ, та вже 1 вересня 1940 р. А. Криленка зараховують викладачем (на 0,5 ставки) кафедри марксизму-ленінізму Львівського університету ${ }^{29}$.

Його однолітком була Валентина Михайлівна Лелюх, котра народилася 17 грудня 1912 р. у с. Лісовичі Таращанського повіту Київської губернії (тепер однойменного району Київської обл.) у селянській сім’ї, українка. По закінченні семирічної школи у м. Тараща навчалась у місцевому сільськогосподарському технікумі (1929-1931). Попрацювавши рік агротехніком на науково-дослідній станції у с. Миронівка Київської області, у 1932 р. поступила на плановоекономічний відділ Одеського сільськогосподарського інституту (тепер Одеський державний аграрний університет). Після першого ж року навчання перевелася на історичний факультет місцевого університету, який закінчила у 1937 р. Член ВЛКСМ (1935) та ВКП(б) (1940). У 1937-1939 рр. - методист історії Кам'янець-Подільського обласного методичного кабінету, у 19391940 pp. - викладач історії в місцевому вчительському інституті (тепер Кам'янець-Подільський національний педагогічний університет імені Івана Огієнка). У червні 1940 р. іiі викликали до Києва для навчання на курсах викладачів основ марксизму-ленінізму при ЦК КП(б)У, після чого (серпень 1940 р.) скерували на роботу викладачем на однойменну кафедру до Львівського університету. Відомо, що вона була одружена, ііі чоловік був працівником одного із районних комітетів КП(б)У у м. Львові ${ }^{30}$.

\footnotetext{
${ }^{28}$ Олександр Луцький, “Науково-організаційна і педагогічна діяльність І. П. Крип’якевича у вересні 1939 - червні 1941 рр.," 798.

29 Личное дело аспиранта Криленко Антона Корнеевича, 9 грудня 1939 р. - 22 жовтня 1940 р., Архів ЛНУ, ф. Р-119, оп. 1, спр. 1445, арк. 1, 2-3, 4, 7; Накази ректора за 1940 р. (друга половина), 72.

30 Дело о поступлении в аспирантуру Лелюх Валентины Михайловны, 19 вересня 1940 р. 21 листопада 1940 р., Архів ЛНУ, ф. Р-119, оп. 1, спр. 1543, арк. 2-3, 4, 5-6; Накази ректора за 1940 р. (друга половина), 150.
} 
Ненабагато старшим за них був і Олександр Захарович Куліков. Народився він 1 серпня 1909 р. у м. Черкаси у робітничій сім'ї. Закінчив у 1933 р. Херсонський педагогічний інститут імені Н. Крупської (тепер - Херсонський державний університет), отримавши фах викладача соціяльно-економічних дисциплін. Того ж року навчався на Харківських курсах підготови викладачів вищої школи (відділ ленінізму) при ЦК КП(б)У. Член ВЛКСМ (1926) та ВКП(б) (1931). У подальшому працював викладачем згаданого Херсонського педагогічного інституту (1933-1936), Вищої комуністичної сільськогосподарської школи імені Л. Кагановича в Одесі (1936), заввідділом пропаганди міського партійного комітету у м. Херсоні (1937-1938), директором обласних курсів партійних робітників у м. Миколаєві (1938-1939), заступником завідувача відділу пропаганди Миколаївського обкому КП(б)У та, зрештою, знову викладачем Херсонського педінституту (серпень-вересень 1939 р.). Саме звідти його скерували на педагогічну роботу до Львова, де він, за сприянням М. Марченка, заступив на початку листопада того ж року посаду старшого викладача основ марксизму-ленінізму Львівського університету ${ }^{31} \mathrm{i}$, паралельно, від травня до липня 1940 р., виконував обов'язки помічника ректора із заочної освіти ${ }^{32}$.

Наведене вище дозволяє ствердити, що всі аспіранти по кафедрі історії України були “перевіреними" радянськими людьми зі зрозумілим минулим, членами ВКП(б) (а О. Куліков деякий час навіть був секретарем партійної організації університету! ${ }^{33}$ ) викладачами університетської кафедри марксизму-ленінізму. Вони не мали за собою ні більшого наукового досвіду, ані жодних публікацій, не знали чужоземних мов (при вступі в аспірантуру і В. Лелюх, і О. Куліков отримали на іспиті з чужоземної мови оцінки "незадовільно"з4), однак, що важило для керівництва, були цілком благонадійними. Недаремно в листі начальника управління вищої школи НКО УРСР О. Філіпова ректорові Львівського університету Георгієві Биченку підкреслювалося, що при доборі кандидатів в аспірантуру треба орієнтуватись не лише на їх здібності і високу академічну підготову, але й на політичну свідомість і відданість інтересам радянської влади ${ }^{35}$. Наголошувати на особливому підборі аспірантів по кафедрі історії України дозволяє порівняти їх з тими особами, що були зараховані по кафедрі археології.

31 Личное дело аспиранта Куликова Александра Захаровича, 21 мая 1940 р. - 2 октября 1940 р., Архів ЛНУ, ф. Р-119, оп. 1, спр. 1446, арк. 2-3зв, 4, 5, 6; Отдел кадров. Заявления лиц о приеме их на работу в качестве профессоров и преподавателей с приложением автобиографий и списка научных работ, 29 січня 1940 р. - 4 березня 1941 р., Архів ЛНУ, ф. Р-119, оп. 1, спр. 427, арк. 42, 49; Накази ректора за 1939 р., 1939, Архів ЛНУ, ф. Р-119, оп. 3, спр. 3, арк. 32.

${ }^{32}$ Накази ректора за 1940 р., 1940 р., Архів ЛНУ, ф. Р-119, оп. 3, спр. 30, арк. 177, 232.

${ }^{33}$ Микола Волянюк, Павло Головко. "Буремні роки. Львівський університет в період Великої Вітчизняної війни (1941-1945рр.),” За радянську науку, 27 травня, 1966; Павло Головко, Микола Волянюк, “Їх імена і подвиги безсмертні,” За радянську науку, 9 травня, 1975.

${ }^{34}$ Відділ кадрів. Списки осіб, рекомендованих до аспірантури, арк. 1.

${ }^{35}$ Приказы и распоряжения Всесоюзного комитета по делам высшей школы при СНК СССР о приеме в аспирантуру с приложением Положения об аспирантуре, арк. 14-14зв. 
ISSN 2078-6077. Наукові зошити історичного факультету Львівського університету. 2020. Випуск 21. Proceedings of History Faculty of Lviv University. 2020. Issue 21.

Тут ситуація виглядала цілком інакше. Один з них - Роман Іванович Тимчук, народився 7 січня 1916 р. в с. Тур'я Лопатинського р-ну (тепер - Буського р-ну) на Львівщині в сім'ї священика. У 1934-1940 рр. навчався у Львівському університеті, студіював класичну археологію та філологію, добре володів німецькою, польською, дещо гірше французькою мовою. Після організації у Львові відділу київського Інституту археології Р. Тимчука ніби-то було призначено його асистентом ${ }^{36}$. Інший - Григорій Єлисеєвич Самчук народився 1 січня 1913 р. в с. Дермань (тепер - Здолбунівського р-ну) біля Рівного. У 1936 р. він поступив на історико-філологічний факультет Варшавського університету, де вивчав археологію у професора В. Антонєвіча, а після осені 1939 р. навчався на історичному факультеті Львівського університету, який закінчив у 1940 р. Влітку того ж року Г. Самчук відбув археологічну практику під керівництвом Я. Пастернака у Крилосі ${ }^{37}$. Як бачимо, обидва аспіранти кафедри археології були вихідцями з західноукраїнських земель, навчалися в університетах міжвоєнної Польщі, володіли на належному рівні чужоземними мовами (при вступі в аспірантуру на іспиті з чужоземної мови Р. Тимчук отримав оцінку “відмінно" 38 ) та, чи не найголовніше, були добре ознайомлені із предметом своїх майбутніх студій. Чим пояснити таку відмінність у підборі аспірантів по кафедрах історії України та археології? Спокусливою видається можливість говорити про особливу увагу радянської влади до проф. І. Крип'якевича як одного із провідників західноукраїнського інтелектуального середовища того часу. Однак, на нашу думку, важливим був інший чинник: археологічним студіям не надавали настільки важливого значення як загальноісторичним. Нагадаємо, що коли в 1946 р. у Львові ліквідували відділ Інституту історії АН УРСР, відділ Інституту археології продовжував діяти. Та й у міжвоєнний період, у роки діяльности Університету Яна Казимира, за часів практично тотальної полонізації гуманістичного факультету, чи не єдиними кафедрами історичного профілю, на яких працювали, хоча й асистентами, українці, були кафедри доісторичної (М. Смішко) та класичної (І. Старчук) археології.

\footnotetext{
${ }^{36}$ Про цей факт з біографії Р. Тимчука згадував у повоєнні роки сам Я. Пастернак (Ярослав Пастернак, "Історична секція НТШ в час другої світової війни," в Сьогочасне й минуле. Вісник украӥнознавства, (Мюнхен - Нью-Йорк, 1948), кн. 1: 38). Втім, праця Р. Тимчук у львівському відділі Інституту археології навряд чи протривала довго. Припускаємо, що вже на час вступу до аспірантури він полишив, а чи був змушений полишити це місце. У всілякому випадку у 1941 p. серед працівників відділу він вже не значився (Олександр Ситник, Археологічна наука у Львові. Перша половина ХХ століття. (Львів - Жешів, 2012), 170-171). До слов, Р. Тимчук, як аспірант Я. Пастернака, брав участь у Крилоській експедиції 1941 р. (Тарас Романюк, Ярослав Пастернак. Життєпис вченого. (Львів: Манускрипт, 2018), 328).

37 Личное дело по учету кадров аспиранта Тимчука Романа Ивановича, б. р., Архів ЛНУ, ф. Р-119, оп. 1, спр. 1453, арк. 1-2; Личное аспиранта Самчука Григория Елисеевича, б. р., Архів ЛНУ, ф. Р-119, оп. 1, спр. 1449, арк. 1, 2, 4; Історичний факультет Львівського національного університету, 189.

${ }^{38}$ Відділ кадрів. Списки осіб, рекомендованих до аспірантури, арк. 2.
} 
Роботу зі своїми аспірантами I. Крип'якевич розпочав наприкінці січня 1941 р. Саме тоді А. Криленка, В. Лелюх та О. Кулікова запросили на засідання кафедри історії України, де, після традиційних привітань з успішним вступом, накреслено план їх подальшої праці ${ }^{39}$. Досвід роботи з аспірантами був для їх керівника новим. Ні австрійські, ні польські університети подібної практики підготови наукових кадрів не знали. Початкові навички дослідницької роботи у студентів цих університетів із середини XIX ст. формувалися у рамках семінарів, які проводили керівники (професори) кафедри ${ }^{40}$. У подальшому студентові потрібно було отримати звання магістра, що передбачало здачу низки іспитів, та підготувати відповідну роботу. Далі потрібно було написати і захистити докторську працю (так званий докторат) i, якщо претендент прагнув викладати в університеті, пройти габілітацію та отримати офіційне (затверджене урядом) призначення (veniam legendi) на кафедру. Лише після того він міг, як приватдоцент чи ад’юнкт, запропонувати студентам свої курси до вибору. Відзначимо, що така система не встановлювала жорстких часових рамок для написання i захисту відповідних робіт та не носила обов'язкового характеру - якихось офіційно затверджених планів з набору чи вишколу майбутніх дослідників просто не існувало, більше того, не було ніяких гарантій їх майбутнього працевлаштування. Як показує практика міжвоєнного часу, шлях до університетської кафедри чи роботи із студентами був доволі звивистим і тривалим. Часто-густо потрібно було довший час попрацювати асистентами у так званих Закладах чи Інститутах, що діяли при кафедрах, або науково працювати в архівах, бібліотеках чи музеях, здобути певне ім'я (реноме) в науковому світі та серед відповідних фахівців і, лише після того, подаватися до захисту ${ }^{41}$.

Натомість запроваджена у радянських вишах у 1925 р. практика вишколу наукових кадрів через аспірантуру була цілком відмінноюㄹ. Положення про

${ }^{39}$ Протоколы заседаний ученого совета по вопросу работы кафедры истории Украины, 1940 р., ДАЛО, ф. Р-119, оп. 3, спр. 66, арк. 8-9.

${ }^{40}$ Ірина Глушик, “Історичний семінар як форма фахового вишколу істориків у Львівському університеті в другій половині XIX ст.," в Історія та історики у Львівському університеті: традииї та сучасність (До 75-ліття створення історичного факультету): колективна монографія, редактор Леонід Зашкільняк та Павло Сєрженги, (Львів: ПАІС, 2015), 354-355; Agnieszka Kowalec, "Seminaria historyczne na Uniwersytecie Lwowskim: podstawy prawne i organizacja (1852-1918),” в Історія та історики у Львівському університеті: традииії та сучасність, 342-344.

${ }^{41}$ Нагадаємо, для прикладу, що І. Крип'якевич завершив навчання у Львівському університеті в 1909 р., а докторат захистив у 1911 р., маючи у своєму доробку приблизно 150 різного роду публікацій. Габілітуватися в Університеті Яна Казимира (а саме таку назву, нагадаємо, носив Львівський університет у 1919-1939 рр.) він не зміг через політичні причини, а тому, попри вагоме наукове реноме, до викладання у ньому допущений не був.

42 Див. про це: Ірина Регейло, "Підготовка фахівців вищої кваліфікації в Україні в 19301939 рр.," Науковий вісник Мелітопольського державного педагогічного університету імені Богдана Хмельницького. Серія: Педагогіка, по. 1(12), (2014): 81-90; Николай Цеховой, "Организационно-правовое оформление системы советской аспирантуры: основные этапы и особенности,” Вестник Томского государственного университета, (2012): 111-115. 
ISSN 2078-6077. Наукові зошити історичного факультету Львівського університету. 2020. Випуск 21. Proceedings of History Faculty of Lviv University. 2020. Issue 21.

аспірантуру від 31 березня 1939 р. не лише передбачало вступні іспити для претендентів, але й обумовлювало для них низку інших вимог, встановлювало чіткі часові рамки навчання (три роки), суворо регламентувало етапи підготови та написання тексту кандидатської дисертації. Передбачалося, що аспіранти, окрім виконання власне наукової роботи та ії подальшого захисту, обов'язково повинні були відвідувати теоретичні заняття, брати активну участь в методичній роботі кафедри, ходити на лекції свого керівника, регулярно здавати різного роду проміжні іспити (у тому числі - кандидатські мінімуми), проходити наукововиробничу практику та, починаючи від другого року навчання, вести педагогічну роботу з оплатою не більше $50 \%$ від ставки асистента. Все це значно утруднювало написання ними кандидатських дисертацій - на це просто бракувало часу, а від їх наукового керівника вимагало розумного підходу до кожного із своїх підопічних.

I. Крип'якевич намагався в роботі з аспірантами використати той досвід, котрий він отримав у роки свого навчання та формування як дослідника, та прилаштуватися до офіційних радянських вимог, а тому поряд із вивченням діялектичного матеріялізму (100 год.), історії філософії (40 год.) та чужих мов I. Крип'якевич провадив індивідуальні консультації, укладав списки необхідної для них літератури та прочитав спеціяльний курс “Методології історії” (30 год.), базований на працях тих закордонних істориків-позитивістів, завдяки яким він сформувався сам (Е. Бернгайм, Ш. Лянглуа, Ш. Сеньобос, Г. Моно) ${ }^{43}$. Тимчасову (до затвердження офіційної) програму роботи для своїх аспірантів професор оголосив уже на засіданні кафедри історії України 31 січня 1941 р., відразу після виходу наказу про офіційне зарахування. Ця програма передбачала опрацювати належну підручникову та спеціяльну літературу з фондів бібліотеки кафедри, участь у першій науковій сесії викладачів Львівського університету (та проходила якраз у цей час - від 29 січня до 3 лютого 1941 р.), обрати майбутнім вченим вужчу спеціяльність у рамках загального курсу історії України тощо ${ }^{44}$. Мали б вони (аспіранти) й “думати вже про дисертацію”, однак через особливості тогочасного навчання в аспірантурі, коли тематика наукових студій

${ }^{43}$ Отчет о работе кафедры истории Украины в 1939-1940 и 1940-1941 учебных годах, 25 червня 1941 р., ДАЛО, ф. Р-119, оп. 3, спр. 278, арк. 4; Индивидуальный план аспиранта кафедры истории Украины Куликова Александра Захаровича, лютий 1941 р. - червень 1941 р., ДАЛО, ф. Р-119, оп. 3, спр. 293, арк. 1зв; Требования аспирантов на приобретение необходимой литературы для учебы, 29 березня 1941 р. - 21 квітня 1941 р., ДАЛО, ф. Р-119, оп. 3, спр. 295, арк. 16, 17, 19; Аспірантура 1945 р. Методика, б. р., Відділ рукописів Львівської національної наукової бібліотеки імені Василя Стефаника (далі - ВР ЛННБ), Архів І. Крип’якевича, спр. 173/ 17, арк. 41. Праці Е. Бернгайма для своїх аспірантів у 1920-х рр. зробив обов'язковими і М. Грушевський. Див.: В'ячеслав Артюх, Тяглість історії й історія тяглості: украӥнська філософсько-історична думка першої половини ХХ століття: монографія. (Суми: Вид-во СумДУ, 2010), 54.

${ }^{44}$ Протоколы заседаний ученого совета по вопросу работы кафедры истории Украины, 1940 р., арк. 8зв. -9 . 
визначалася ближче до кінця першого року, впевнено говорити про тему майбутнього кандидатського дослідження підопічних I. Крип'якевича можемо лише у випадку зарахованого на другий рік навчання А. Криленка. Його перебування в аспірантурі завершувалося раніше, ніж в інших - 31 січня 1943 р., а тому й часу щоб готувати та написати роботу було менше. Тему його дисертаційної праці було визначено як “Запоріжжя в другій половині XVII віку" 45 , що, за задумом наукового керівника, передбачала всестороннє відобразити політичний лад, економіку та соціальне розшарування на Запоріжжі в той час. Якоюсь тематикою, пов'язаною з історією України XVI-XVII ст., повинна була б займатися і В. Лелюх. У будь-якому випадку саме такими хронологічними рамками була визначено ії вузький фах ${ }^{46}$. Історію України пізнішого часу досліджував О. Куліков - полем його майбутніх студій визначили середину XIX -XX ст. (так званий “капіталістичний” і радянський періоди) ${ }^{47}$. Зрештою, навряд чи всі вони встигли достатньо далеко просунутися у своїх наукових пошуках упродовж лютого - червня 1941 р., враховуючи той факт, що в той час аспіранти I. Крип'якевича, хто більше, хто менше, продовжували працювати викладачами, хоча й на 0,5 ставки, по кафедрі марксизму-ленінізму ${ }^{48}$. Початок радянсько-німецької війни, як відзначено у звіті кафедри історії України від 25 червня 1941 р., завадив згаданим аспіранти здати всі передбачені індивідуальними планами заліки ${ }^{49}$. Подальші події кардинально змінили долю цих людей. Згідно з відомостями, віднайденими нами в об’єднаній базі даних "Меморіал”, капітан А. Криленко, командир дивізіону 12 гвардійського артилерійського полку, помер від ран на Курщині у березні 1943 р., а командир 6-ої стрілецької роти 836-го стрілецького полку 240 стрілецької дивізії лейтенант О. Куліков загинув наприкінці лютого 1945 р. на території Чехословаччини ${ }^{50}$. Що

${ }^{45}$ Индивидуальные планы учебно-научной подготовки аспирантов (А-К), 18 лютого 1941 р. 27 лютого 1941 р., ДАЛО, ф. Р-119, оп. 3, спр. 294, арк. 86.

${ }^{46}$ Индивидуальные планы подготовки аспирантов кафедр исторического факультета, 1940 р., ДАЛО, ф. Р-119, оп. 3, спр. 187, арк. 1-2.

${ }^{47}$ Индивидуальный план аспиранта кафедры истории Украины Куликова Александра Захаровича, лютий 1941 р. - червень 1941 р., арк. 1.

${ }^{48}$ Накази ректора [Львівського університету] за 1941 р., 118, 169.

${ }^{49}$ Отчет о работе кафедры истории Украины в 1939-1940 и 1940-1941 учебных годах, арк. 4.

50 “Іменний список безповоротних втрат офіцерського складу 240-ї стрілецької КиївськоДніпровської червонопрапорної орд.[енів] Суворова і Богдана Хмельницького дивізії за період 3 15 лютого по 25 лютого 1945 р.," Мемориал, доступ отримано 12 вересня 2018 p., https://www.obdmemorial.ru/html/info.htm?id=73804538; "Наказ Головного управління кадрів Народного комісаріату оборони СРСР № 054 /пог. від 8 травня 1943 р.,” Мемориал, доступ отримано 12 вересня 2018 р., https://www.obd-memorial.ru/html/info.htm?id=57319836; "Наказ Головного управління кадрів Народного комісаріату оборони СРСР по особовому складу армії № 01538 від 2 червня 1945 р.," Мемориал, доступ отримано 12 вересня 2018 p., https:/www.obd-memorial.ru/html/ info.htm?id=74756677; Микола Волянюк, Павло Головко. "Буремні роки. Львівський університет в період Великої Вітчизняної війни (1941-1945рр.)," За радянську науку, 27 травня, 1966; Павло Головко, “Про них збережемо пам'ять,” За радянську науку, 30 вересня, 1966; Павло Головко, Микола Волянюк, “Їх імена і подвиги безсмертні,” За радянську науку, 9 травня, 1975. 
ISSN 2078-6077. Наукові зошити історичного факультету Львівського університету. 2020. Випуск 21. Proceedings of History Faculty of Lviv University. 2020. Issue 21.

сталося в роки радянсько-німецької війни та у наступний час з В. Лелюх - не відомо, однак до подальшого навчання в аспірантурі у Львівському університеті вона так і не зголосилася.

У Львівському університету аспірантуру відновили у повоєнний час ${ }^{51}$. Наказ ректора Львівського університету I. Бєлякевича від 22 жовтня 1945 р. передбачав набір до аспірантури на історичному факультеті за спеціяльностями “історія України” та “нова історія”. До іспитової комісії на чолі з проректором 3 наукової роботи проф. Романом Волковим залучили І. Бєлякевича, проф. I. Крип'якевича та старшого викладача кафедри історії середніх віків О. Терлецького. За результатами проведених випробувань наказом ректора від 12 грудня 1945 р. до зарахування (остаточне рішення приймало союзне Міністерство вищої освіти ${ }^{52}$ ) в аспірантуру рекомендували Ніну Василівну Цимбал (1922-?) та Володимира Олександровича Бориса (1914-1985), обох по кафедрі історії України ${ }^{53}$. Їхнім науковим наставником було призначено єдиного на той час на історичному факультеті професора та доктора наук.І. Крип'якевича.

I B. Борис, i Н. Цимбал були тогорічними випускниками Львівського університету, а тому їх добре знали на факультеті. Щоправда, їх соціяльне та periональне походження було різним. В. Борис був, що називається, “місцевим”: народився в селянській сім'ї у м. Яворові, де й навчався у народній школі (19221926) та Гуманістичній гімназіі. Після вступу у 1936 р. на гуманістичний факультет Львівського університету вивчав історію та німецьку мову. Від часу радянізації вишу, продовжив студії на історичному факультеті, закінчити який зумів лише у повоєнний час. У березні-липні 1940 р. йому довелося попрацювати старшим препаратором по кафедрі історії України ${ }^{54}$. Н. Цимбал походила 3

${ }^{51}$ Постанова РНК УРСР, якою затверджувався план прийому аспірантів до Львівського університету, датована 22 травнем 1945 р. Див.: Наказ Всесоюзного Комітету в справах вищої школи при РНК СРСР і листування з Управлінням вищої школи НКО УРСР про створення аспірантури і план прийому в аспірантуру, 2 січня 1944 р. - 19 жовтня 1945 р., ДАЛО, ф. Р-119, оп. 10, спр. 1, арк. 5.

52 Відомі випадки, коли згадане Міністерство не затверджувало осіб, яких рекомендував до зарахування Львівський університет. Див., наприклад: Звіт про роботи аспірантури за 1947/ 1948 навчальний рік, 1947-1948 рр., ДАЛО, ф. Р-119, оп. 10, спр. 9, арк. 2.

${ }_{53}^{53}$ Копії наказів ректора, 2 січня 1945 р. - 27 грудня 1945 р., Архів ЛНУ, ф. Р-119, оп. 6, спр. 7, арк. 206, 237 зв. Вступники повинні були здавати іспити до аспірантури у два етапи: місцеві - від 25 до 31 жовтня, приїжджі- від 10 до 15 листопада 1945 р. Загалом того навчального року до аспірантури в університеті було прийнято 15 (при початковому плані 16) осіб: 13 першого року навчання та двоє другого. Див.: Статистичний звіт (ф. № 82-К) про кількість і розподіл аспірантів по кафедрах на початок 1945/1946 навчального року, 1945 р., ДАЛО, ф. Р-119, оп. 10, спр. 2, арк. 3-4.

${ }^{54}$ Відділ кадрів. Заявления лиц о приеме их на работу, с приложением автобиографий и личных листов по учету кадров и копий дипломов, 10 января 1939 г. - 31 декабря 1940 г., Архів ЛНУ, ф. Р-119, оп. 1, спр. 1429, арк. 2, 3;Особова справа Бориса Володимира Олександровича, б. р., Архів ЛНУ, ф. Р-119, оп. 2/ос., спр. 1219, арк. 2-3, 4-4зв., 65; Накази ректора за 1940 р., арк. 107, 207-208; Микола Крикун, “Борис Володимир Олександрович," в ENCYCLOPEDIA. Львівський національний університет імені Івана Франка. (Львів, 2011), т. 1, 232. 
Одещини, а їі батьки була службовцями. Врешті-решт, їх кандидатури затвердило союзне Міністерство вищої освіти, однак попрацювати з ними обома I. Крип'якевичу не довелося: у березні 1946 р. В. Бориса перевели до аспірантури на кафедру історії нового часу (цьому сприяло його добре знання німецької, англійської, французької та польської мов ${ }^{55}$ ), а його керівником призначили запрошеного з Одеси дослідника історії Франції кінця XVIII ст. проф. Костянтина Павловича Добролюбського $(1887-1953)^{56}$. Хто $з$ університетських одеситів (ректор І. Бєлякевич чи декан історичного факультету В. Горбатюк) запропонував "підсилити" цим вченим історичний факультет у Львові - не відомо, однак така співпраця не принесла більших результатів жодній стороні, адже К. Добролюбський у повоєнний час був деканом та завідувачем кафедри історичного факультету Одеського університету, а тому у Львові працював у 1945-1949 pр. за сумісництвом ${ }^{57}$. Відповідно В. Борис не міг тішитися особливою увагою професора, який перебував в Одесі, а не у Львові. Їхнє спілкування відбувалося у формі листів, у яких К. Добролюбський обіцяв консультувати В. Бориса, погоджував запропоновану тему майбутньої дисертації тощо. Однак наскільки дієвою могла стати така допомога молодому вченому у його науковій роботі - можемо лише припускати. Відомо, для прикладу, що у 1947 р. В. Борису не вдалося здати низку іспитів зі спеціялізації, через те, як відзначено в довідці, що К. Добролюбський переїхав на роботу до Одеси (! - О. Ц.). Для ліквідації цієї заборгованости передбачалося відрядити аспіранта до його керівника ${ }^{58}$.

Зрештою, першою повоєнною аспіранткою I. Крип'якевича стала згадана Н. Цимбал ${ }^{59}$. Народилася вона 5 серпня 1922 р. у містечку II-Миколаївка

553 часом В. Борис навіть здобув другу вищу освіту на факультеті іноземних мов Львівського університету (1953р.), а впродовж 1945-1950рр. працював викладачем німецької та англійської мови в Українському інституті кооперативної торгівлі (тепер - Львівський торговельноекономічний університет) та у Львівській музичній школі-десятирічці (тепер - Львівська музична школа-інтернат ім. С. Крушельницької).

${ }^{56}$ Особова справа аспіранта Бориса Володимира Олексійовича, 1 січня 1946 р. - 1 січня 1949 р., Архів ЛНУ, ф. Р-119, оп. 1, спр. 14а, арк. 4-4зв.; Копії наказів ректора, 2 січня 1946 р. 30 грудня 1946 р., Архів ЛНУ, ф. Р-119, оп. 6, спр. 16, арк. 48.

57 До речі, К. Добролюбський упродовж 1946-1948 рр. був (чи, радше, рахувався) членом Вченої Ради Львівського університету та Ради історичного факультету по захисту кандидатських дисертацій. Див.: Постанова Ради Міністрів УРСР і ЦК КП(б)У, Накази Міністерства вищої освіти СРСР, наркома освіти УРСР і листування про їх виконання, 4 лютого 1946 р. - 5листопада 1946 р., ДАЛО, ф. Р.-119, оп. 6, спр.12, арк. 84, 90-92; Вчена Рада. Протоколи і стенограми засідань Вченої Ради університету, 12 січня 1946 р. - 9 грудня 1946 р., ДАЛО, ф. Р.-119, оп. 8, спр. 2, арк. 6; Вчена Рада. Протоколи і стенограми засідань Вченої Ради університету, т. 1, 21 січня 1947 р. - 27 вересня 1947 р., ДАЛО, ф. Р.-119, оп. 8, спр. 3, арк. 104; Вчена Рада. Протоколи і стенограми засідань Вченої Ради університету, т. 2, 15 березня 1948 р. - 6 травня 1948 р., ДАЛО, ф. Р.-119, оп. 8, спр.7, арк. 90.

${ }^{58}$ Статистичні звіти (ф. 82-к) про кількість і розподіл аспірантів по кафедрах за 1946/1947 навчальний рік, 1946-1947 рр., ДАЛО. ф. Р.-119, оп. 10, спр. 5, арк. 7.

${ }^{59}$ Біографічні дані про неї взято у: Особова справа аспіранта Цимбал Ніни Василівни, 1946 р., Архів ЛНУ, ф. Р-119, оп. 2а, спр. 9, арк. 2-2 зв., [21-22зв], [31-31зв.]; Личное дело студента Цымбал Нины Васильевны, 1944 р., Архів ЛНУ, оп. 1, спр. [12], арк.1, 5-5зв.; [Особова справа] Цимбал Ніни Василівни, б. р., спр. 8392, арк. 7-8, 10, 11. 
ISSN 2078-6077. Наукові зошити історичного факультету Львівського університету. 2020. Випуск 21. Proceedings of History Faculty of Lviv University. 2020. Issue 21.

Ананьївського повіту Херсонської губернії (тепер - смт. Миколаївка однойменного району Одеської області). Навчалася спочатку у місцевій школі, а далі, у зв'язку із переїздом її батьків до Одеси, продовжила свою освіту у СШ № 50 цього міста. У вересні 1939 р. вступила на історичний факультет місцевого університету, однак, коли в серпні 1940 р. іiі батька скерували завідувачем районного відділу освіти у м. Щирець біля Львова, Н. Цимбал перевели на другий курс історичного факультету Львівського університету. Із початком радянськонімецької війни евакуювалася до Ставропольського краю, а у 1943 р. - до Казахстану, де працювала викладачем історії, службовцем у політвідділах місцевих МТС, начальником спецчастини міськвиконкому. У березні 1944 р., після відходу німців, повернулася в Україну, ставши уповноваженим райкому партії в одному із колгоспів Чернігівщини, а в жовтні 1944 р. відновила студії у Львівському університеті. Від осені 1944 р. до весни 1945 р., паралельно із навчанням, спочатку на III, а пізніше, після окремого переведення, на IV курсі ${ }^{60}$, була комсоргом університету, а від березня 1945 р. працювала старшим лаборантом кафедри історії народів СРСР ${ }^{61}$. У січні 1945 р. вступила до ВКП(б). Керівником іiі дипломної роботи (“Полтавська битва 1709 р.”) був завідувач кафедри В. Осечинський. Із років навчання Н. Цимбал в Одеському університеті iii знав декан історичного факультету Львівського університету В. Горбатюк ${ }^{62}$. У вересні 1945 р. Н. Цимбал призначили викладачем по кафедрі марксизмуленінізму ${ }^{63}$, звідки вона і потрапила до аспірантури. Тема ії кандидатської дисертації (зрештою, так і не завершеної) неодноразово змінювалася ${ }^{64}$, і врештірешт була визначена як “Спільна боротьба запорізького і донського козацтва проти турецько-татарської агресії у другій половині XVI - першій половині

${ }^{60}$ Наказом ректора I. Бєлякевича в січні 1945 р. їі перевели з III на IV курс історичного факультету з умовою доздати належні іспити. Див.: Відділ кадрів. Накази ректора університету по особовому складу, 17 листопада 1944 р. - 31 січня 1945 р., Архів ЛНУ, ф. Р-119, оп. 28 /Ос, спр. 2, арк. 60 .

${ }^{61}$ Накази ректора університету ім. І. Франка за 1944 р., 1 серпня 1944 р. - 28 грудня 1944 р., Архів ЛНУ, ф. Р-119, оп. 6, спр. 2, арк. 47.

62 Личное дело студента Цымбал Нины Васильевны, арк. 3.

${ }^{63}$ Копії наказів ректора, 2 січня 1945 р. - 27 грудня 1945 р., арк. 203. Пропрацювала на цій посаді до вересня 1946 р. (Копії наказів ректора, 2 січня 1946 р. - 30 грудня 1946 р., ,арк. 200). Від жовтня 1946 р. до квітня 1947 р. - викладач кафедри історії України (Копії наказів ректора, 2 січня 1946 р. - 30 грудня 1946 р., арк. 224зв.; Накази ректора Львівського університету за 1947 р., т. 1, 4 січня 1947 р. - 26 травня 1947 р., Архів ЛНУ, ф. Р-119, оп. 6, спр. 22, арк. 164).

${ }^{64}$ Вчена Рада. Протоколи і стенограми засідань Вченої Ради університету, 12 січня 1946 р. 9 грудня 1946 р., арк. 179, 182. Після вступу Н. Цимбал до аспірантури (лютий 1946 р.) тему іï кандидатської роботи було визначено як “Суспільно-політичний рух в Галичині в другій половині XIX ст. і Росія”. Аспірантка працювала (чи починала працювати) над цією темою до вересня 1946 р. Саме тоді новим напрямком ï наукових студій, попри певний супротив ректора I. Бєлякевича, обрано стосунки запорозьких і донських козаків у XVII ст. Див.: Аспірантура 1945-1946, 1945-1946, ВР ЛННБ, спр. 250, папка Н. В. Цимбал, арк. [5-5зв.];

Аспірантура 1945 р. Методика, б. р., спр. 173/4, арк. 4, 6, 6зв. 
XVII ст.”"65. Припускаємо, що запропонував її I. Крип'якевич, котрий тоді особливо цікавився козацькими часами та Хмельниччиною. Та й, як уже згадувалося, тема одного із “довоєнних" аспірантів - А. Криленка перегукувалася з цією назвою.

Наступного навчального року до аспірантури по кафедрі історії України поступив ще один випускник історичного факультету Василь Фадейович Інкін (22.02.1922-31.01.1999) ${ }^{66}$. Народився на Чернігівщині, росіянин за походженням, він в 1940 р. завершив з відзнакою школу та влаштувався на роботу завідувачем бібліотеки Чернігівської авіяшколи. Через наступ німецьких військ евакуювався на схід, у глиб Радянського Союзу, де восени вступив на історичний факультет Педагогічного інституту у м. Чкаловськ. У квітні 1944 р. повернувся в Україну та працював декілька місяців вчителем історії та німецької мови Мохнатинської СШ Чернігівського р-ну. Від вересня 1944 р. - студент історичного факультету Ніжинського державного педагогічного інституту імені М. В. Гоголя, однак вже за місяць його перевели на навчання до Львівського університету. В. Інкіна, як одного із найкращих студентів, залишили на факультеті, призначивши у вересні 1946 р. асистентом кафедри історії народів СРСР. Цілком логічним виглядав i подальший вступ В. Інкіна до аспірантури. Що стосується назви майбутньої дисертаційної роботи молодого вченого, то ії перший, "робочий” варіянт (“Лев Данилович, галицький князь”) визначено ще у січні 1947 p. ${ }^{67}$ Щоправда, впродовж наступних місяців тему скорегували та дещо розширили, і звучала вже як "Галицько-Волинське князівство у другій половині XIII і першій половині XIV ст." ${ }^{68}$. Виходячи 3 цього, загальним фахом для В. Інкіна було обрано історію

\footnotetext{
${ }^{65}$ [Особова справа] Цимбал Ніни Василівни, б. р., арк. 5-6; Отчет о научно-исследовательской работе [Львовского педагогического] Института за 1952 год, 1952 р., ДАЛО, Ф. Р-7, оп. 1, спр. 93, арк. 18-18зв.

${ }^{66}$ Про навчання В. Ф. Інкіна в аспірантурі та його роботу над кандидатською дисертацією докладніше див.: Олександр Целуйко, "Про одну ненаписану дисертацію. Причинок до вивчення історії галицько-волинської держави у повоєнну добу,”: 176-199. Біографічні дані про вченого автор отримав із його особових справ (Особова справа аспіранта Інкіна Василя Фадейовича, 1947-1950 pp., Архів ЛНУ, ф. Р-119, оп. 1, спр. 49а; Особова справа Інкіна Василя Фадейовича, 20 лютого 1946 р., ф. Р-119, оп. 1, спр. 348; Особова справа Інкіна Василя Фадейовича, б. д., Архів ЛНУ, ф. Р-119, оп. 3, спр. 4610) та окремих публікацій (Микола Крикун, “Передмова," у Сільське суспільство Галицького Прикарпаття у XVI-XVIII століттях, IX-XIV; Олег Павлишин, “Інкін Василь Фадейович," в Історичний факультет Львівського національного університету імені Івана Франка, 104-105). Принагідно відзначимо, що початково в аспірантуру по кафедрі історії України було заплановано два місця, однак прийнято лише одну людину (Відомості про підготовку наукових працівників через аспірантуру за 1945/1946 - 1947/1948 навчальні роки, б. д., ДАЛО, ф. Р-119, оп. 10, спр. 13, арк. 1, 5). Тоді ж (у січні 1947 р.) аспірантом по кафедрі нової історії країн Сходу прийняли М. О. Ратича (Накази ректора Львівського університету за 1947 р., т. 1, арк. 36).

67 Аспірантура 1945 р. Методика, арк. 21 зв.

${ }^{68}$ Кафедра історії УРСР. Протоколи засідань за 1944/1945, 1945/1946, 1946/1947, 1947/1948 навчальні роки, 3 серпня 1944 р. - 27 квітня 1948 р., ДАЛО, ф. Р-119, оп. 17, спр. 6, арк. 26зв.
} 
ISSN 2078-6077. Наукові зошити історичного факультету Львівського університету. 2020. Випуск 21. Proceedings of History Faculty of Lviv University. 2020. Issue 21.

України періоду феодалізму; вузьким фахом - історію Київської держави і феодальних князівств XII-XIV ст. ${ }^{69}$

У жовтні 1947 р. аспіранткою по кафедрі історії України стала випускниця Львівського державного педагогічного інституту та сталінський стипендіят Ольга Федотівна Омельчук (1923-?). Походила вона із бідної української селянської сім'ї з с. Лебеди Острозького району Рівненської обл. Ще у студентські роки вступила до ВКП (б), що мало б сприяти іiі кар'єрному росту в майбутньому ${ }^{70}$. Після закінчення навчання ії зарахували асистентом кафедри історії України педінституту (вересень 1947 р.), а через місяць вона поступила до аспірантури в університет, ставши де-факто останньою аспіранткою I. Крип'якевича у Львівському університеті ${ }^{71}: 1$ жовтня 1947 р. Івана Петровича призначили їі науковим керівником, а 3-го листопада того ж року його усунули 3 роботи в університеті, офіційно - через порушення міністерської директиви про впорядкування сумісництва ${ }^{72}$.

Як уже відзначено раніше, I. Крип'якевич достатньо уважно ставився до навчання аспірантів, детально визначаючи програму та план їхньої праці, намагався домогтися, щоб у них було якомога більше часу для наукової роботи. Кафедра регулярно розглядала питання про їх роботу, заслуховувала звіти, наукові реферати (не менше одного на півроку ${ }^{73}$ ) та виступи. Щоправда ні В. Інкін, ні Н. Цимбал (О. Омельчук залишаємо за рамками цього розгляду через надто короткий термін співпраці із керівником) вчасно захиститися не змогли. Причини цього були такі ж, як і у попередній період. Особливості тогочасного вишколу майбутніх науковців, де власне, щоб написати дисертацію, відводився останній рік навчання, зміна тематики студії, надмірна завантаженість лекціями та курсами в аспірантурі, підготова до здачі численних кандидатських мінімумів, які приймалися чи не кожного семестру ${ }^{74}$, необхідність заробляти додаткові кошти, оскільки аспірантської стипендії для утримання сім’ї не вистачало (Н. Цимбал, для прикладу, одна виховувала доньку, оскільки іiі чоловік загинув у роки радянсько-німецької війни ${ }^{75}$ ), усе це аж ніяк не допомагало їхній науковій роботі.

\footnotetext{
${ }^{69}$ Особова справа аспіранта Інкіна Василя Фадейовича, 1-2.

${ }^{70}$ [Особова справа аспіранта] Омельчук-Семенової Ольги Федотівни, 1 жовтня 1947 р. - 1 жовтня 1950 р., Архів ЛНУ, ф. Р-119, оп. 1, спр. 16, арк. 21-21зв.

${ }^{71}$ Щоправда, в червні 1947 р. проф. І. Крип’якевича призначили консультантом викладача Ужгородського університету С. Кондор, котра готувала кандидатську дисертацію “Просвітники Закарпаття другої половини ХІХ ст.”. Див.: Накази ректора ЛДУ ім. Ів. Франка за 1947 р.. т. 2, 26 травня 1947 р. - 02 серпня 1947 р., Архів ЛНУ, ф. Р-119, оп. 6, спр. 23, арк. 108. Науковим керівником $€$. Кондор була доц. Ганна Глядківська, під керівництвом якої та захистила у 1949 р. кандидатську роботу про революційний селянський рух на Закарпатті. Див.: Акти обстеження роботи аспірантури за 1950-51 рік, 21 березня 1951 р. - 29 березня 1951 р., ДАЛО, ф. Р-119, оп. 10, спр. 29, арк. 13; Кафедра історії СРСР. Протоколи засідання кафедри, 4 вересня 1948 р. - 2 липня 1949 р., ДАЛО, ф. Р-119, оп. 17, спр. 97, арк. 35-36.

${ }^{72}$ Накази ректора Львівського державного університету ім. Ів. Франка за 1947 р., т. 3, 2 серпня 1947 р. - 1 листопада 1947 р., Архів ЛНУ, ф. Р-119, оп. 6, спр. 24, арк. 163, 177; Штатный формуляр профессорско-преподавательского состава на 1947/49 учебные годы, 1947/1949, ДАЛО, ф. Р-7, оп. 1, спр. 46, арк. 2.
} 
Зрештою, як уже згадувалося, Н. Цимбал та В. Інкін під час навчання в аспірантурі викладали на історичному факультеті Львівського педінституту, що теж не давало змоги належно виконувати навчальний план аспіранта.

Найдовше (січень 1946 - осінь 1947 р.) працювала 3 І. Крип'якевичем Н. Цимбал. Ще на засіданні кафедри в січні 1946 р. затвердили план ії роботи в аспірантурі, а опісля почалося докладне навчання та студії. Н. Цимбал прослухала низку лекцій І. Крип'якевича 3 методики історії, палеографії, методики досліджень, вчилася провадити дипломатичний аналіз документів та читала історіографічні праці, у тому числі М. Грушевського ${ }^{76}$. Дещо інакше стояла справа із В. Інкіним, адже той став аспірантом I. Крип'якевича практично у розпал ідеологічної кампанії боротьби зі школою М. Грушевського. Одним з ії наслідків був вимушений переїзд I. Крип'якевича до Києва i, хоча за ним на кафедрі історії України Львівського університету залишили частину педагогічного навантаження, насамперед керівництво аспірантурою, все цезначно утруднювало контакти між професором та його учнями. У матеріялах особистого фонду I. Крип'якевича збереглися чернетки та копії низки навчальних матеріялів по роботі із аспірантами, у тому числі зошит, де професор фіксував усі свої офіційні контакти з ними. У них, окрім часу та місця зустрічі, записувалися ті завдання, які вони отримували від свого наукового керівника, та позначки про їх виконання. Завдяки цьому знаємо, наприклад, що вперше із В. Інкіним як зі своїм аспірантом Іван Петрович зустрівся 9 грудня 1946 р., коли йому вдалося навідатися до Львова. Всього таких “офіційних” зустрічей було принаймні півтора десятка. Відбувалися вони нерегулярно, інколи у приватному помешканні професора, інколи у приміщенні кафедри історії України, а деколи й поряд 3 університетом, на чистому повітрі, у парку ім. Івана Франка. Число та час цих зустрічей співвідносилися, насамперед, із перебуванням І. Крип'якевича у місті. Так, три наступних зустрічі відбулися 15, 19 і 21 січня 1947 р.; ще дві - 12 і 15 березня. Інша “весняно-літня сесія" мала місце наприкінці травня - на початку червня 1946 р. (31 травня, 2, 4, 7, 12, 13 червня); далі - 1 серпня, а потім - 22, 25 і 28 вересня того

${ }^{73}$ Кафедра історії України, 1944-[19]46 рр., ВР ЛННБ, Архів І. Крип’якевича, спр. 248, арк. [5-5зв].

${ }^{74}$ Для прикладу, зі звіту Н. Цимбал за першу половину 1946 р. дізнаємося, що за цей час вона відвідувала заняття 3 французької мови, прослухала курс лекцій І. Крип’якевича 3 методики наукової роботи та палеографії та, під його керівництвом, написала реферат на тему "Палеоліт України”, опрацювала низку позицій необхідної їй літератури з давньої історії України та палеографії тощо. (Аспірантура 1945-1946, 1945-1946, тека Н. В. Цимбал, арк. [34-37]). Протягом аналогічного періоду за 1947 р. Н. Цимбал здала два іспити з історії України, заліки 3 джерелознавства та історіографії України, склала конспекти шести лекцій для спецкурсу та написала два реферати, один з яких був заслуханий на кафедрі. (Стенограма наради аспірантів, 12 листопада 1946 р., ДАЛО, ф. Р-119, оп. 10, спр. 4, арк. 11-12). І це ще не враховано те педагогічне навантаження, яке вона виконувала на факультеті у Львівському університеті!

${ }^{75}$ [Особова справа] Цимбал Ніни Василівни, арк. 5-6.

${ }^{76}$ Аспірантура 1945-1946, 1945-1946, тека Н. В. Цимбал, арк. [4-4зв., 8, 34-37, 57-58]. 
ISSN 2078-6077. Наукові зошити історичного факультету Львівського університету. 2020. Випуск 21. Proceedings of History Faculty of Lviv University. 2020. Issue 21.

ж року ${ }^{77}$. Із Н. Цимбал проф. І. Крип'якевич зустрічався впродовж вересня 1946-вересня 1947 pp. 14 разів (9 та 23 вересня, 12 та 19 листопада, 1 грудня 1946 р., 16 січня, 13 березня, 2, 7 та 16 червня, 10 липня, 14 серпня, 25 та 27 вересня 1947 p. $^{78}$ ). Двічі - 24 та 27 вересня 1947 р. - відвідала I. Крип’якевича у нього вдома й О. Омельчук ${ }^{79}$.

Якою була подальша доля повоєнних аспірантів І. Крип'якевича? Склалася вона по-різному. Звільнили проф. І. Крип'якевича, треба було, очевидно, призначити їм нових керівників. Оскільки ніхто із викладачів кафедри історії України стати ним не міг через брак належних вчених звань, вирішили звернутися по допомогу до працівників інших кафедр та навіть університетів. Врешті-решт, керувати колишніми аспірантами I. Крип'якевича з різницею у декілька місяців доручили старшому викладачеві кафедри історії народів СРСР Григорієві Гербільському ${ }^{80}$. Припускаємо, що саме під його впливом було змінено тематику кандидатської роботи В. Інкіна, яку 10 червня 1949 р. затвердили як “Становище селян Самбірської економії у XVIII ст.” ${ }^{21}$. Зрештою, у червні 1949 р. у Львівському університеті кафедру історії України ліквідовали, долучивши ії до кафедри історії народів $\mathrm{CPCP}^{82}$. Сюди ж перевели й колишніх аспірантів I. Крип'якевича. Очевидно, що такого роду пертурбації не могли позитивно впливати на умови та терміни підготови їхніх наукових робіт. Найвідомішим 3 них, безперечно, став В. Інкін, котрий захистив не лише кандидатську (1955), але й докторську (1978) дисертації. Ще в листопаді 1948 р. його призначили асистентом, а в 1951 р. - старшим викладачем кафедри історії СРСР Львівського державного педагогічного інституту ${ }^{83}$. Після ліквідації історичного факультету цього вишу в 1956 р. В. Інкіна перевели до Львівського університету, де він

77 Аспірантура 1945 р. Методика, б. р., спр. 173/4, арк. 21-23зв.

78 Там само. Арк. 5зв.-8.

79 Там само. Арк. 39.

${ }^{80}$ Кафедра історії УРСР. Протоколи засідань за 1944/1945, 1945/1946, 1946/1947, 1947/1948 навчальні роки, арк. 55зв.; Накази ректора [Львівського] університету за 1948 р., 5 січня 1948 р. - 20 травня 1948 р., Архів ЛНУ, ф. Р-119, оп. 6, спр. [15], арк. 114, 185; Накази ректора Львівського університету за 1948 р., т. 2, 21 травня 1948 р. - 30 вересня 1948 р., Архів ЛНУ, ф. Р-119, оп. 6, спр. 33, арк. 60.

${ }^{81}$ Особова справа аспіранта Інкіна Василя Фадейовича, арк. 9. Принагідно додамо, що ще раніше - у листопаді 1946 р., тобто практично відразу після початку “заслання” І. Крип’якевича до Києва, змінити напрямок наукових пошуків мала б і Н. Цимбал: ректор І. Бєлякевич хотів, щоби вона повернулася до своєї початкової теми та вивчала соціяльно-політичний рух в Галичині на початку ХХ ст. та вплив на нього російської революції 1905 р. (Вчена Рада. Протоколи і стенограми засідань Вченої Ради університету, 12 січня 1946 р. - 9 грудня 1946 р., арк. 182). Цього, однак, не сталося.

${ }^{82}$ Накази, директивні вказівки Міністерства вищої освіти СРСР, Управління в справах вищої школи при Раді Міністрів УРСР і Міністерства геології СРСР, 6 січня 1949 р. - 28 грудня 1949 р., ДАЛО, ф. Р-119, оп. 6, спр. 39, арк. 32.

83 Див. про це у: Олександр Целуйко, “Історичний факультет Львівського державного педагогічного інституту та політичні кампанії другої половини 1940-х рр.,” в Старий Луиьк. Науково-інформаційний збірник, по. 12, (Луцьк, 2016), 452-470. 
працював до 1997 р. Старший викладач, доцент (1959-1979) та професор (19801992) кафедри історії СРСР, iї завідувач у 1970-1973 pp. В. Інкін був однією із знакових постатей на факультеті, науковцем, чиє ім'я було добре відоме серед фахівців з давньої та ранньомодерної історії України.

Що стосується Н. Цимбал, то вона, як і В. Інкін, у 1947-1956 рр. працювала старшим викладачем по кафедрі історії СРСР місцевого педінституту, а у подальшому - на аналогічній посаді на кафедрі історії Львівського відділення Вищої партійної школи та у Львівському лісотехнічному інституті. У $1957-$ 1960 pp. Н. Цимбал, як погодинник, час від часу підпрацьовувала у Львівському університеті на кафедрі історії СРСР ${ }^{84}$. Відомостей про захист нею кандидатської роботи автор не віднайшов ${ }^{85}$. У Львівському педінституті довший час працювала і О. Омельчук (після одруження у 1948 р. вона перейшла на прізвище Семенова). Попри те, що вона закінчила аспірантуру, захистити вчасно свою кандидатську роботу (“Революційний рух на Волині в час панування панської Польщі (1935-1939рр.)”) теж не змогла. Із середини 1950-х рр. ії сліди губляться.

Власне на цьому завершимо розповідь про тих аспірантів проф. I. Крип'якевича, з якими він працював у стінах Львівського університету у 19411947 рр. Протягом довшого часу цей відомий і цілком сформований дослідник був позбавлений шансу працювати із університетською молоддю, готувати наукову зміну. Перебудова роботи Львівського університету, що стартувала восени 1939 р., здавалося б, творила нові можливості у розвитку української історичної освіти. Відкривши кафедру історії України, запросивши на роботу низку українських фахівців, збільшивши прийом на навчання української молоді створено, як стало швидко зрозуміло, лише ілюзію поступу українтсва в Галичині. Врешті решт накресленим планам не судилося збутися. І якщо перші аспіранти I. Крип'якевича перервали своє навчання влітку 1941 p. через початок німецькорадянської війни, то їх повоєнні колеги були позбавлені можливости продовжувати вчитись під керівництвом I. Крип'якевича із суто політичних обставин. Наскільки успішною виявилася би ця співпраця учня М. Грушевського і його молодих радянських колег, старшого галицького вченого і сформованих за цілком відмінних ідеологічних умов студентів радянських вишів, які плоди їхня спільна праця принесла б - це питання залишимо відкритим. Зрештою, зреалізувати себе як наставника наукової молоді, сформувати навколо себе групу осіб, котра б продовжили його працю, I. Крип'якевичу частково вдалося у подальшому, у

84 [Особова справа] Цимбал Ніни Василівни, арк. 1, 3-4, 5-6, 9-12, 15-21.

${ }^{85}$ Єдина відома нам публікація авторства Н. Цимбал - (“Викриття буржуазногонаціоналістичної фальсифікації історії Жовтневої соціалістичної революції на Україні” в книзі Торжество ідей ленінізму. (К., 1957. С. 498-517)) була написана у співавторстві із старшим викладачем кафедри історії СРСР Львівського університету Г. Черних. Див.: Друковані праці професорів, викладачів і співробітників Львівського університету за 1944-1960 роки. Бібліографічний покажчик. (Львів, 1962), 115. 
ISSN 2078-6077. Наукові зошити історичного факультету Львівського університету. 2020. Випуск 21. Proceedings of History Faculty of Lviv University. 2020. Issue 21.

1950-1960-х рр., за часів роботи в Інституті суспільних наук та діяльности Теоретичного семінару з джерелознавства та спеціяльних (допоміжних) історичних дисциплін. Можливість зробити це швидше, у 1940-х рр., була змарнована, і змарнована зовсім не з вини вченого.

\title{
ALIENS OR ALLIANCE? THE POSTGRADUATES OF IVAN KRYPYAKEVYCH IN LVIV UNIVERSITY: AN ATTEMPT OF PROSPOGRAPHIC PORTRAIT
}

\author{
Oleksandr TSELUIKO \\ The Ivan Franko National University of Lviv \\ The Department of the Ancient Ukrainian History and Archival Studies \\ 1 University str., Lviv 79000, Ukraine \\ e-mail: o_celujko@meta.ua
}

The Soviet system for training scientific and pedagogical workers at special postgraduate course was introduced at Lviv State University as a part of its Sovietization. The first group of postgraduates was accepted in the fall-winter of 1940-1941. At that time, four people were taken to postgraduate course of Faculty of History, and two of them (Valentyna Lelyukh and Olexander Kulikov) were enrolled in Department of History of Ukraine. Their official postgraduate courses began on February 1, 1941, and ended on January 31, 1944. Anton Krylenko joined the postgraduates at Department of History of Ukraine in the middle of February, 1941. He was enrolled as a postgraduate student in the second year of study, because he had already studied at postgraduate course in Kyiv. The well-known Ukrainian scientist professor Ivan Krypiakevych was appointed as the official head of these postgraduates at Department of History of Ukraine.

As a result of a detailed study of the biographies of these postgraduate students of Lviv University, it was found that they were all from the eastern regions of Ukraine, they only recently had arrived in Lviv and had been the members of the VKP (b) (All-Union Communist Party (Bolsheviks)). They did not have any more scientific experience, nor any publications, they did not know foreign languages, however, which they were important for the Soviet leadership. This allows to talk about a special selection of postgraduates in the Department of History of Ukraine, especially in comparison with other Departments of the University.

Krypiakevych began the work with his postgraduates in late January, 1941. He conducted individual consultations and compiled the lists of necessary literature but at the same time, I. Krypiakevych adapted his work with postgraduates to the official Soviet demands on education.

The postgraduate courses at Lviv University were restored after the war. In December, 1945 Nina Tsymbal and Volodymyr Borys were recommended to enroll in the postgraduate study at Department of History of Ukraine. Prof. I.Krypiakevych was again appointed as their scientific tutor. After some time, Borys was moved to postgraduate study at another Department, and only Tsymbal remained under the direction of Krypiakevych. In the next academic year, another graduate of Faculty of History, Vasyl Inkin began his post-graduate course at Department of History of Ukraine. In October, 1947 Olga Omelchuk, which has been a graduate of the Lviv State Pedagogical Institute, became postgraduate too. In November, 1947 Krypiakevych was officially dismissed from the University. After some time, a new supervisor was appointed for these postgraduates.

Keywords: Lviv University, Department of History of Ukraine, Ivan Krypiakevych. 


\section{References}

Agnieszka Kowalets, "Seminaria historyczne na Uniwersytecie Lwowskim: podstawy prawne i organizacja (1852-1918)," v Istoriya ta istoryky u Lvivskomu universyteti: tradyciyi ta suchasnist (Do 75-littya stvorennya istorychnoho fakuletu): kolektyvna monohrafiya, redaktor Leonid Zashkilnyak ta Pavlo Syerzhengy. Lviv: PAIS, 2015, 342-353. (in Polish).

Akty obstezhennya roboty aspirantury za 1950-51 rik, 21 bereznya 1951 r. -29 bereznya 1951 r., Derzhavnyy Arkhiv Lvivskoyi Oblasti, Fond R-119, Opys 10, Sprava 29. (in Ukrainian)

Artyukh, Vyacheslav. Tyahlist istoriyi j istoriya tyahlosti: ukrayinska filosofsko-istorychna dumka pershoyi polovyny XX stolittya: monohrafiya. Sumy: Vydavnyctvo SumDU, 2010. (in Ukrainian).

postgraduate course1945 r. Metodyka, b. r., Viddil Rukopysiv Lvivskoyi prats Naukovoyi Biblioteky Imeni Vasylya Stefanyka, Arkhiv I. Krypyakevycha, Sprava 173. (in Ukrainian).

postgraduate course1945-1946, 1945-1946 rr., Viddil Rukopysiv Lvivskoyi Natsionalnoyi Naukovoyi Biblioteky Imeni Vasylya Stefanyka, Arkhiv I. Krypyakevycha, Sprava 250. (in Ukrainian).

Bezdrabko, Valentyna. "Seminar z arkhivoznavstva ta dopomizhnykh istorychnykh dyscyplin CDIA Ukrayiny u Lvovi: naukovyj fenomen," Zapysky Lvivskoyi naukovoyi biblioteky im. V. Stefanyka: Zbirnyk naukovykh prats, No. 1 (16), (2008): 546-579. (in Ukrainian).

Bezdrabko, Valentyna. Dokumentoznavstvo v Ukrayini: instytucionalizaciya ta suchasnyy rozvytok. Kyyiv: "Chetverta khvylya", 2009. (in Ukrainian).

Cekhovoy, Nikolay. "Organizacionno-pravovoe oformlenie sistemy sovetskoj aspirantury: osnovnye ehtapy i osobennosti," Vestnik Tomskogo gosudarstvennogo universiteta, (2012): 111-115. (in Russian).

Delo o Postuplenii v Aspiranturu Lelyuh Valentiny Mihajlovny, 19 Sentjabrja 1940. - 21 Nojabrja 1940 g., Arkhiv Lvivskoho Natsionalnoho Universytetu Imeni Ivana Franka, Fond R-119, Opys 1, Sprava 1543. (in Ukrainian).

Drukovani Pratsi Profesoriv, Vykladachiv i Spivrobitnykiv Lvivskoho Universytetu za 19441960 rr. Bibliohrafichnyy Pokazhchyk. Lviv, 1962. (in Ukrainian).

Hnatyuk, Olha. Vidvaha i strax. Kyyiv: DUX I LITERA, 2017. (in Ukrainian).

Holovko, Pavlo, i Volyanyuk, Mykola. "Yix imena i podvyhy bezsmertni," Za radyansku nauku, May 9, 1975. (in Ukrainian).

Holovko, Pavlo. "Pro nyx zberezhemo pam'yat, Za radyansku nauku, September 30, 1966. (in Ukrainian).

"Imennyy spysok bezpovorotnyx vtrat oficerskoho skladu 240-yi strileckoyi KyyivskoDniprovskoyi chervonoprapornoyi ord.[eniv] Suvorova i Bohdana Khmelnytskoho dyviziyi za period z 15 lyutoho po 25 lyutoho 1945 r.," Memoryal, accessed September 12, 2018, https://www.obd-memorial.ru/html/info.htm?id=73804538. (in Russian).

Individualnye Plany Podgotovki Aspirantov Kafedr Istoricheskogo Fakulteta, 1940 g., Derzhavnyy Arkhiv Lvivskoyi Oblasti, Fond R-119, Opys 3, Sprava 187. (in Ukrainian).

Individualnye Plany Uchebno-Nauchnoj Podgotovki Aspirantov (A-K), 18 Fevralja 1941 g. 27 Fevralja 1941 g., Derzhavnyy Arkhiv Lvivskoyi Oblasti, Fond R-119, Opys 3, Sprava 294. (in Ukrainian).

Individualnyy plan aspiranta kafedry istorii Ukrainy Kulikova Aleksandra Zaharovicha, lyutyj 1941 r. - cherven 1941 r., Derzhavnyy Arkhiv Lvivskoyi Oblasti, Fond R-119, Opys 3, Sprava 293. (in Ukrainian). 
ISSN 2078-6077. Наукові зошити історичного факультету Львівського університету. 2020. Випуск 21. Proceedings of History Faculty of Lviv University. 2020. Issue 21.

Instytut istoriyi Ukrayiny Natsionalnoyi akademiyi nauk Ukrayiny. Dokumenty i materialy. 1936-1991. Kyyiv: Instytut istoriyi Ukrayiny NAN Ukrayiny, 2011, kn. 1. (in Ukrainian).

Iryna Hlushyk, "Istorychnyy seminar yak forma fakhovoho vyshkolu istorykiv u Lvivskomu universyteti v druhiy polovyni XIX st.," v Istoriya ta istoryky u Lvivskomu universyteti: tradytsiyi ta suchasnist (Do 75-littya stvorennya istorychnoho fakultetu): kolektyvna monohrafiya, redaktor Leonid Zashkilnyak ta Pavlo Syerzhengy. Lviv: PAIS, 2015, 354363. (in Ukrainian).

Isayevych, Yaroslav. "Krypyakevych Ivan Petrovych" v Encyklopediya istoriyi Ukrayiny. Kyyiv, 2008, t. 5, 390-395. (in Ukrainian).

Istorychnyj Fakultet Lvivskoho Natsionalnoho Universytetu Imeni Ivana Franka (1940 2000). Yuvilejna Knyha, uporyadnyky Oleksij Vinnychenko, i Oleksandr Celujko. Lviv, 2000. (in Ukrainian).

Ivan Krypyakevych u Rodynnij Tradyciyi, Nautsi, Suspilstvi (Ukrayina: Kulturna Spadshhyna, Nacionalna Svidomist, Derzhavnist. Zbirnyk Naukovykh Prats), No. 8, (2001). (in Ukrainian).

Ivan Krypyakevych u Rodynnij Tradytsiyi, Nautsi, Suspilstvi (Ukrayina: Kulturna Spadshhyna, Natsionalna Svidomist, Derzhavnist. Zbirnyk Naukovykh Prats), No. 28, (2016). (in Ukrainian).

Kachmar, Volodymyr, i Prytula, Yaroslav. "Istorychnyy Fakultet u Strukturi Lvivskoho Universytetu: 1940 rik," Visnyk Lvivskoho Universytetu. Seriya Istorychna, No. 50, (2014): 418-447. (in Ukrainian).

Kachmar, Volodymyr. "Mizh "radyanizaciyeyu" ta "ukrayinizaciyeyu": diyalnist Mykhayla Marchenka na posadi rektora Lvivskoho universytetu v 1939-1940 rokakh," v Lviv: misto - suspilstvo - kulturà. Krakiv: Naukove vydavnyctvo Pedahohichnoyi Akademiyi, 2005, t. V. Lyudy Lvova, 141-155. (in Ukrainian).

Kachmar, Volodymyr. "Reorhanizaciya Lvivskoho Universytetu (1939-1940)," Naukovi Zoshyty Istorychnoho Fakutetu. Lvivskyy Natsionalnyy Universytet Imeni Ivana Franka, No. 7, (2005): 328-338. (in Ukrainian).

Kafedra istoriyi SRSR. Protokoly zasidannya kafedry, 4 veresnya 1948 r. - 2 lypnya 1949 r., Derzhavnyy Arkhiv Lvivskoyi Oblasti, Fond R-119, Opys 17, Sprava 97. (in Ukrainian).

Kafedra Istoriyi Ukrayiny, 1944-1946, Viddil Rukopysiv Lvivskoyi Natsionalnoyi Naukovoyi Biblioteky Imeni Vasylya Stefanyka, Arkhiv I. Krypyakevycha, Sprava 248.

Kafedra Istoriyi URSR. Protokoly Zasidan za 1944/1945, 1945/1946, 1946/1947, 1947/1948 Navchalni Roky, 3 Serpnya 1944 r. - 27 Kvitnya 1948 r., Derzhavnyy Arkhiv Lvivskoyi Oblasti, Fond R-119, Opys 17, Sprava 6. (in Ukrainian).

Kopiyi Nakaziv Rektora, 2 Sichnya 1945 r. - 27 Hrudnya 1945 r., Arkhiv Lvivskoho Natsionalnoho Universytetu Imeni Ivana Franka, Fond R-119, Opys 6, Sprava 7. (in Ukrainian).

Kopiyi Nakaziv Rektora, 2 Sichnya 1946 r. - 30 Hrudnya 1946 r., Arkhiv Lvivskoho Natsionalnoho Universytetu Imeni Ivana Franka, Fond R-119, Opys 6, Sprava 16. (in Ukrainian).

Kovtun, Khrystyna, i Synytsya, Andriy. "Andriy Brahinets - pershyy dekan istorychnoho fakultetu Lvivskoho universytetu," Visnyk Lvivskoho universytetu. Seriya istorychna, No. 50, (2014): 183-205. (in Ukrainian).

Krykun, Mykola. "Borys Volodymyr Oleksandrovych" v ENCYCLOPEDIA. Lvivskyy Natsionalnyy Universytet Imeni Ivana Franka. Lviv, 2011, t. 1, 232. (in Ukrainian). 
Krykun, Mykola. "Peredmova," v Inkin, Vasyl. Silske Suspilstvo Halytskoho Prykarpattya u XVI-XVIII Stolittykh: Istorychni Narysy. Lviv, 2004, IX-XIV. (in Ukrainian).

Kuchernyuk, Mykola, i Ivantsev, Ihor. "Ivan Krypyakevych ta yoho lvivska shkola istorykiv" v Tezy dopovidey ta povidomlen rehionalnoyi naukovo-teoretychnoyi konferetsiyi prysvyachenoyi 105-richchyu z dnya narodzhennya vyznachnoho istoryka Ukrayiny, akademika Ivana Krypyakevycha, (Ivano-Frankivsk, 1991): 16-17. (in Ukrainian).

Kyrychuk, Yuriy, i Kondratyuk, Kostyantyn. "Kafedra Novitnoyi Istoriyi Ukrayiny," v Istorychnyy Fakultet Lvivskoho Natsionalnoho Universytetu Imeni Ivana Franka (1940_ 2000). Yuvileyna Knyha, uporyadnyky Oleksiy Vinnychenko, i Oleksandr Celujko. Lviv, 2000, 7-13. (in Ukrainian).

Lichnoe aspiranta Samchuka Grigoriya Eliseevicha, b. r., Arkhiv Lvivskoho Natsionalnoho Universytetu Imeni Ivana Franka, Fond R-119, Opys 1, Sprava 1449. (in Ukrainian).

Lichnoe Delo Aspiranta Królenko Antona Korneevicha, 9 Dekabrja 1939 g. - 22 Oktjabrja 1940 g., Arkhiv Lvivskoho Natsionalnoho Universytetu Imeni Ivana Franka, Fond R-119, Opys 1, Sprava 1445. (in Ukrainian).

Lichnoe Delo Aspiranta Kulikova Aleksandra Zaharovicha, 21 Maja 1940 g. - 2 Oktjabrja 1940 g., Arkhiv Lvivskoho Natsionalnoho Universytetu Imeni Ivana Franka, fond R-119, Opys 1, Sprava 1446. (in Ukrainian).

Lichnoe delo po uchetu kadrov aspiranta Timchuka Romana Ivanovicha, b. r., Arkhiv Lvivskoho Natsionalnoho Universytetu Imeni Ivana Franka, Fond R-119, Opys 1, Sprava 1453. (in Ukrainian).

Lichnoe delo studenta Cymbal Niny Vasil'evny, 1944 r., Arkhiv Lvivskoho Nacionalnoho Universytetu Imeni Ivana Franka, Fond R-119, Opys 1, Sprava [12]. (in Ukrainian).

Lutskyy, Oleksandr. "Naukovo-Orhanizaciyna i Pedahohichna Diyalnist I. P. Krypyakevycha u Veresni 1939 - Chervni 1941 rr. ," v Ivan Krypyakevych u Rodynnij Tradyciyi, Nautsi, Suspilstvi (Ukrayina: Kulturna Spadshchyna, Natsionalna Svidomist, Derzhavnist. Zbirnyk Naukovykh Prats), No. 8, (2001): 783-800. (in Ukrainian).

"Nakaz Holovnoho upravlinnya kadriv Narodnoho komisariatu oborony SRSR ${ }^{1}$ 054/poh. vid 8 travnya 1943 r.," Memoryal, accessed September 12, 2018, https://www.obd-memorial.ru/ html/info.htm?id=57319836. (in Russian).

"Nakaz Holovnoho upravlinnya kadriv Narodnoho komisariatu oborony SRSR po osobovomu skladu armiyi ${ }^{1} 01538$ vid 2 chervnya 1945 r.," Memoryal accessed September 12, 2018 , https://www.obd-memorial.ru/html/info.htm?id=74756677. (in Russian).

Nakaz Vsesoyuznoho Komitetu v spravakh vyshhoyi shkoly pry RNK SRSR i lystuvannya z Upravlinnyam vyshhoyi shkoly NKO URSR pro stvorennya aspirantury i plan pryyomu v aspiranturu. 2 sichnya 1944 r. - 19 zhovtnya 1945 r., Derzhavnyy Arkhiv Lvivskoyi Oblasti, Fond R-119, Opys 10, Sprava 1. (in Ukrainian).

Nakazy rektora [Lvivskoho universytetu] za 1941 r., 1941 r., Arkhiv Lvivskoho Natsionalnoho Universytetu Imeni Ivana Franka, Fond R-119, Opys 3, Sprava 52. (in Ukrainian).

Nakazy Rektora Lvivskoho Derzhavnoho Universytetu Im. Iv. Franka za 1947 r., t. 3 , 2 Serpnya 1947 r. - 1 Lystopada 1947 r., Arkhiv Lvivskoho Natsionalnoho Universytetu Imeni Ivana Franka, Fond R-119, Opys 6, Sprava 24. (in Ukrainian).

Nakazy Rektora Lvivskoho Universytetu za 1947 r., t. 1, 4 Sichnya 1947 r. - 26 Travnya 1947 r., Arkhiv Lvivskoho Natsionalnoho Universytetu Imeni Ivana Franka, Fond R-119, Opys 6, Sprava 22. (in Ukrainian). 
ISSN 2078-6077. Наукові зошити історичного факультету Львівського університету. 2020. Випуск 21. Proceedings of History Faculty of Lviv University. 2020. Issue 21.

Nakazy Rektora Lvivskoho Universytetu za 1948 r., t. 2, 21 Travnya 1948 r. - 30 Veresnya 1948 r., Arkhiv Lvivskoho Natsionalnoho Universytetu Imeni Ivana Franka, Fond R-119, Opys 6, Sprava 33. (in Ukrainian).

Nakazy rektora LDU im. Iv. Franka za 1947 r. t. 2, 26 travnya 1947 r. - 02 serpnya 1947 r., Arkhiv Lvivskoho Natsionalnoho Universytetu Imeni Ivana Franka, Fond R-119, Opys 6, Sprava 23. (in Ukrainian).

Nakazy Rektora Universytetu Im. I. Franka za 1944 r., 1 Serpnya 1944 r. - 28 Hrudnya 1944 r., Arkhiv Lvivskoho Natsionalnoho Universytetu Imeni Ivana Franka, Fond R-119, Opys 6, Sprava 2. (in Ukrainian).

Nakazy Rektora Universytetu za 1948 r., 5 Sichnya 1948 r. - 20 Travnya 1948 r., Arkhiv Lvivskoho Natsionalnoho Universytetu Imeni Ivana Franka, Fond R-119, Opys 6, Sprava 15. (in Ukrainian).

Nakazy rektora za 1939 r., 1939 r., Arkhiv Lvivskoho Natsionalnoho Universytetu Imeni Ivana Franka, Fond R-119, Opys 3, Sprava 3. (in Ukrainian).

Nakazy Rektora za 1940 r. (Druha Polovyna), 1940, Arkhiv Lvivskoho Natsionalnoho Universytetu Imeni Ivana Franka, Fond R-119, Opys 3, Sprava 31. (in Ukrainian).

Nakazy Rektora za 1940 r., 1940, Arkhiv Lvivskoho Natsionalnoho Universytetu Imeni Ivana Franka, Fond R-119, Opys 3, Sprava 30. (in Ukrainian).

Nakazy, Dyrektyvni Vkazivky Ministerstva Vyshhoyi Osvity SRSR, Upravlinnya v Spravakh Vyshhoyi Shkoly pry Radi Ministriv URSR i Ministerstva Heolohiyi SRSR, 6 Sichnya 1949 r. - 28 Hrudnya 1949 r., Derzhavnyy Arkhiv Lvivskoyi Oblasti, Fond R-119, Opys 6, Sprava 39. (in Ukrainian).

Osobova Sprava Aspiranta Cymbal Niny Vasylivny, 1946 r., Arkhiv Lvivskoho Natsionalnoho Universytetu Imeni Ivana Franka, Fond R-119, Opys 2a, Sprava 9. (in Ukrainian).

Osobova Sprava Aspiranta Inkina Vasylya Fadeyovycha, 1947-1950 rr., Arkhiv Lvivskoho Natsionalnoho Universytetu Imeni Ivana Franka, Fond R-119, Opys 1, Sprava 49 a. (in Ukrainian).

[Osobova sprava aspiranta] Omelchuk-Semenovoyi Olhy Fedotivny, 1 zhovtnya 1947 r. - 1 zhovtnya 1950 r., Arkhiv Lvivskoho Natsionalnoho Universytetu Imeni Ivana Franka, Fond R-119, Opys 1, Sprava [16]. (in Ukrainian).

Osobova Sprava Borysa Volodymyra Oleksandrovycha, b. r., Arkhiv Lvivskoho Natsionalnoho Universytetu Imeni Ivana Franka, Fond R-119, Opys 2/os., Sprava 1219. (in Ukrainian).

[Osobova sprava] Tsymbal Niny Vasylivny, b. r., Arkhiv Lvivskoho Natsionalnoho Universytetu Imeni Ivana Franka, Fond R-119, Opys 1, Sprava 8392. (in Ukrainian).

Osobova Sprava Inkina Vasylya Fadeyovycha, 20 Lyutoho 1946 r., Arkhiv Lvivskoho Natsionalnoho Universytetu Imeni Ivana Franka, Fond R-119, Opys 1, Sprava 348. (in Ukrainian).

Osobova Sprava Inkina Vasylya Fadeovycha, b. d., Arkhiv Lvivskoho Natsionalnoho Universytetu Imeni Ivana Franka, Fond R-119, Opys 3, Sprava 4610. (in Ukrainian).

Otchet o nauchno-issledovatelskoy rabote [Lvovskogo pedagogicheskogo] Instituta za 1952 god, 1952 r., Derzhavnyy Arkhiv Lvivskoyi Oblasti, Fond R-7, Opys 1, Sprava 93. (in Ukrainian).

Otchet o Rabote Kafedry Istorii Ukrainy v 1939-1940 i 1940-1941 Uchebnyh Godah, 25 Ijunja 1941 g., Derzhavnyy Arkhiv Lvivskoyi Oblasti, Fond R-119, Opys 3, Sprava 278. (in Ukrainian). 
Otdel kadrov. Zayavleniya lic o prieme ih na rabotu v kachestve professorov i prepodavatelej s prilozheniem avtobiografii i spiska nauchnyh rabot, 29 sichnya 1940 r. - 4 bereznya 1941 r., Arkhiv Lvivskoho Natsionalnoho Universytetu Imeni Ivana Franka, Fond R-119, Opys 1, Sprava 427. (in Ukrainian).

Pasternak, Yaroslav. "Istorychna sekciya NTSh v chas druhoyi svitovoyi viyny," v Sohochasne y mynule. Visnyk ukrayinoznavstva. Myunkhen - Nyu-York, 1948, kn. 1: 37-40. (in Ukrainian).

Pavlyshyn, Oleh. "Inkin Vasyl Fadeyovych," v Istorychnyj Fakultet Lvivskoho Natsionalnoho Universytetu Imeni Ivana Franka (1940-2000). Yuvileyna Knyha, Uporyadnyky Oleksij Vinnychenko, i Oleksandr Celujko. Lviv, 2000, 104-105. (in Ukrainian).

Postanova Rady Ministriv URSR i CK KP(b)U, Nakazy Ministerstva vyshhoyi osvity SRSR, narkoma osvity URSR i lystuvannya pro yix vykonannya, 4 lyutoho 1946 r. - 5lystopada 1946 r., Derzhavnyy Arkhiv Lvivskoyi Oblasti, Fond R-119, Opys 6, Sprava 12. (in Ukrainian).

Prikazy i rasporyazheniya Vsesoyuznogo komiteta po delam vysshej shkoly pri SNK SSSR o prieme v aspiranturu s prilozheniem Polozheniya ob aspiranture, 31 bereznya 1939 r. -30 zhovtnya 1940 r., Derzhavnyy Arkhiv Lvivskoyi Oblasti, Fond R-119, Opys 3, Sprava 150. (in Ukrainian).

Protokoly i stenohramy zasidan Vchenoyi Rady universytetu ta materialy do nykh, t. 2 i ostanniy, 30 chervnya 1953 r. - 7 hrudnya 1953 r., Derzhavnyy Arkhiv Lvivskoyi Oblasti, Fond R-119, Opys 8, Sprava 22. (in Ukrainian).

Protokoly zasedanij Nauchnogo Soveta i prikaz Vsesoyuznogo komiteta po delam vysshej shkoly pri SNK SSSR ot 15 aprelya 1940 g. ob utverzhdenii sostava uchenogo soveta, 4 hrudnya 1939 r. - 15 kvitnya 1940 r., Derzhavnyy Arkhiv Lvivskoyi Oblasti, Fond R-119, Opys 3, Sprava 64. (in Ukrainian).

Protokoly Zasedaniy Uchenogo Soveta po Voprosu Raboty Kafedry Istorii Ukrainy, 1940, Derzhavnyy Arkhiv Lvivskoyi Oblasti, Fond R-119, Opys 3, Sprava 66. (in Ukrainian).

Prytula, Yaroslav. "postgraduate coursena fizyko-matematychnomu fakulteti u 1940-1941 rokax," Mekhaniko-matematychnyy fakultet Lvivskoho natsionalnoho universytetu im. Ivana Franka, February 23, 2017, accessed October 20, 2017, http://www.mmf.lnu.edu.ua/ istoriia/istoriia-fakultetu/1528. (in Ukrainian).

Redzik, Adam. “Uniwersytet Lwowski w Latach 1939-1946,” w Academia Militans. Uniwersytet Jana Kazimierza we Lwowie. Kraków: Wysoki Zamek, 2015, 913-1078. (in Polish).

Rehejlo, Iryna. "Pidhotovka fakhivtsiv vyshhoyi kvalifikatsiyi v Ukrayini v 1930-1939 rr.," Naukovyy visnyk Melitopolskoho derzhavnoho pedahohichnoho universytetu imeni Bohdana Khmelnytskoho. Seriya: Pedahohika, no. 1(12), (2014): 81-90. (in Ukrainian).

Romanyuk, Taras. Yaroslav Pasternak. Zhyttyepys vchenoho. Lviv: Manuskrypt, 2018. (in Ukrainian).

Shtatnyy Formulyar Professorsko-Prepodavatelskogo Sostava na 1947/49 Uchebnye Gody, 1947-1949, Derzhavnyy Arkhiv Lvivskoyi Oblasti, Fond R-7, Opys 1, Sprava 46. (in Ukrainian).

Spiski prepodavatelej, imeyushchih uchenoe zvanie professora, i vypiski iz protokolov zasedani vysshej attestacionnoj komissii ob utverzhdenii prepodavatelej v uchenom zvanii i uchenoj stepeni, 12 bereznya 1941 r. - 7 chervnya 1941 r., Arkhiv Lvivskoho Natsionalnoho Universytetu Imeni Ivana Franka, Fond R-119, Opys 1, Sprava 413. (in Ukrainian). 
ISSN 2078-6077. Наукові зошити історичного факультету Львівського університету. 2020. Випуск 21. Proceedings of History Faculty of Lviv University. 2020. Issue 21.

Statystychni zvity (f. 82-k) pro kilkist i rozpodil aspirantiv po kafedrakh za 1946/1947 navchalnyy rik, 1946-1947 rr., Derzhavnyy Arkhiv Lvivskoyi Oblasti, Fond R-119, Opys 10, Sprava 5. (in Ukrainian).

Statystychnyy zvit (f. ${ }^{1}$ 82-K) pro kilkist i rozpodil aspirantiv po kafedrakh na pochatok 1945/ 1946 navchalnoho roku, 1945 r., Derzhavnyy Arkhiv Lvivskoyi Oblasti, Fond R-119, Opys 10, Sprava 2. (in Ukrainian).

Stenohrama narady aspirantiv, 12 lystopada 1946 r., Derzhavnyy Arkhiv Lvivskoyi Oblasti, Fond R-119, Opys 10, Sprava 4. (in Ukrainian).

Svarnyk, Ivan. "Krypyakevych Ivan Petrovych" v Ukrayinski arkhivisty (XIX-XX st.). Biobibliohrafichnyj dovidnyk. Kyyiv, 2007, 323-325. (in Ukrainian).

Sytnyk, Oleksandr. Arkheolohichna nauka u Lvovi. Persha polovyna XX stolittya. LvivZheshiv, 2012. (in Ukrainian).

Trebovaniya aspirantov na priobretenie neobhodimoy literatury dlya ucheby, 29 bereznya 1941 r. - 21 kvitnya 1941 r., Derzhavnyy Arkhiv Lvivskoyi Oblasti, Fond R-119, Opys 3, Sprava 295. (in Ukrainian).

Tseluiko, Oleksandr. "Istorychnyy Fakultet Lvivskoho Derzhavnoho Pedahohichnoho Instytutu ta Politychni Kampaniyi Druhoyi Polovyny 1940-x rr.," v Staryj Lutsk. NaukovoInformacijnyj Zbirnyk. Lutsk, 2016, no. 12, 452-470. (in Ukrainian).

Tseluiko, Oleksandr. "Kafedra istoriyi Ukrayiny u 1944-1949 rr.: vid uchniv Mykhayla Hrushevskoho do apolohetiv radyanskoho svitu," Visnyk Lvivskoho universytetu. Seriya istorychna, no. 54, (2018). (in Ukrainian).

Tseluiko, Oleksandr. "Pro odnu nenapysanu dysertaciyu. prychynok do vyvchennya istoriyi halytsko-volynskoyi derzhavy u povoyennu dobu," Visnyk Lvivskoho universytetu. Seriya istorychna, No. 52, (2016): 176-199. (in Ukrainian).

Tseluiko, Oleksandr. "V. V. Zvarych ta pytannya numizmatyky v roboti teoretychnoho seminaru $\mathrm{z}$ dzhereloznavstva ta specialnykh (dopomizhnyx) istorychnykh dyscyplin pry Centralnomu derzhavnomu istorychnomu arkhivi URSR u Lvovi," Naukovi zoshyty istorychnoho fakultetu Lvivskoho universytetu, No. 16, (2015): 24-39. (in Ukrainian).

Ukaz Prezidiuma Verhovnogo Soveta USSR o prisvoenii universitetu im.[eni] Ivana Franko, prikazy VSHVK pri SNK SSSR o provedenii ehkzamenacionnoj sessii i utverzhdenii personalnogo sostava gosudarstvennyh ehkzamenacionnyh komissij, 1 hrudnya $1940 \mathrm{r}$. 7 kvitnya 1941 r., Derzhavnyy Arkhiv Lvivskoyi Oblasti, Fond R-119, Opys 3, Sprava 29. (in Ukrainian).

Vchena Rada. Protokoly i stenohramy zasidan Vchenoyi Rady universytetu, 12 sichnya 1946 r. -9 hrudnya 1946 r., Derzhavnyy Arkhiv Lvivskoyi Oblasti, Fond R-119, Opys 8, Sprava 2. (in Ukrainian).

Vchena Rada. Protokoly i stenohramy zasidan Vchenoyi Rady universytetu, t. 1, 21 sichnya 1947 r. - 27 veresnya 1947 r., Derzhavnyy Arkhiv Lvivskoyi Oblasti, Fond R-119, Opys 8, Sprava 3. (in Ukrainian).

Vchena Rada. Protokoly i stenohramy zasidan Vchenoyi Rady universytetu, t. 2, 15 bereznya 1948 r. - 6 travnya 1948 r., Derzhavnyy Arkhiv Lvivskoyi Oblasti, Fond R-119, Opys 8, Sprava 7. (in Ukrainian).

Viddil Kadriv. Nakazy Rektora Universytetu po Osobovomu Skladu, 17 Lystopada 1944 r. -31 Sichnya 1945 r., Arkhiv Lvivskoho Natsionalnoho Universytetu Imeni Ivana Franka, Fond R-119, Opys 28 /Os, Sprava 2. (in Ukrainian). 
Viddil kadriv. Spysky aspirantiv, [1941], Arkhiv Lvivskoho Nacionalnoho Universytetu Imeni Ivana Franka, Fond R-119, Opys 1, Sprava 1456. (in Ukrainian).

Viddil kadriv. Spysky aspirantiv, 20 sichnya 1941 r. -8 kvitnya 1941 r., Arkhiv Lvivskoho Natsionalnoho Universytetu Imeni Ivana Franka, Fond R-119, Opys 1, Sprava 1457. (in Ukrainian).

Viddil kadriv. Spysky osib, rekomendovanyx do aspirantury, [1940], Arkhiv Lvivskoho Natsionalnoho Universytetu Imeni Ivana Franka, Fond R-119, Opys 1, Sprava 1458. (in Ukrainian).

Viddil Kadriv. Zajavlenija Lic o Prieme Ih na Rabotu, s Prilozheniem Avtobiografij i Lichnyh Listov po Uchetu Kadrov i Kopij Diplomov, 10 Janvarja 1939 g. - 31 Dekabrja 1940 g., Arkhiv Lvivskoho Nationalnoho Universytetu Imeni Ivana Franka, Fond R-1 19, Opys 1, Sprava 1429. (in Ukrainian).

Vidomosti pro pidhotovku naukovykh pratsivnykiv cherez aspiranturu za 1945/1946 - 1947/ 1948 navchalni roky, b. d., Derzhavnyy Arkhiv Lvivskoyi Oblasti, Fond R-119, Opys 10, Sprava 13. (in Ukrainian).

"Vlasnoruchni svidchennya v'yaznya M. I. Marchenka pro yoho robotu rektorom Lvivskoho derzhavnoho universytetu im. I. Franka u 1939-1940 pp., 30 travnya 1943 r.," v Instytut istoriyi Ukrayiny Natsionalnoyi akademiyi nauk Ukrayiny. Dokumenty i materialy. 19361991. Kyyiv: Instytut istoriyi Ukrayiny NAN Ukrayiny, 2011), kn. 1, 377-399. (in Ukrainian).

Volodymyr Hrabovetskyy, "Lvivska istorychna shkola akademika Ivana Krypyakevycha. Uchni Lvivskoyi istorychnoyi shkoly Ivana Krypyakevycha 50-70-x rokiv XX st. ta yix naukovi zdobutky," v Akademik Ivan Krypyakevych. Ivan-Frankivsk, 2005. (in Ukrainian).

Volyanyuk, Mykola, i Holovko, Pavlo. "Buremni roky. Lvivskyy universytet v period Velykoyi Vitchyznyanoyi viyny (1941-1945 rr.)," Za radyansku nauku, May 27, 1966. (in Ukrainian).

Zabolotna, Inna. "Istoriohrafiya zhyttya ta naukovoyi spadshhyny I. P. Kryp'yakevycha," Istoriohrafichni doslidzhennya v Ukrayini, No. 17, (2017): 210-217. (in Ukrainian).

Zvit pro roboty aspirantury za 1947/1948 navchalnyy rik, 1947-1948 rr., Derzhavnyy Arkhiv Lvivskoyi Oblasti, Fond R-119, Opys 10, Sprava 9. (in Ukrainian). 